Review

\title{
The Role of Pathogenic Autoantibodies in Autoimmunity
}

\author{
Merrill J. Rowley * and Senga F. Whittingham \\ Department of Molecular Biology and Medicine, Monash University, Clayton 3168, Australia; \\ E-Mail: senga.whittingham@monash.edu
}

* Author to whom correspondence should be addressed; E-Mail: merrill.rowley@monash.edu; Tel.: +61-3-9902-9357; Fax: +61-3-9902-9500.

Academic Editor: Christiane Hampe

Received: 27 August 2015 / Accepted: 3 November 2015 / Published: 10 November 2015

\begin{abstract}
The serological presence of autoantibodies is diagnostic of autoimmunity, and these autoantibodies may be present for many years before the presentation of autoimmune disease (AID). Although a pathogenic role has been demonstrated for various autoantibodies reactive with cell surface and extracellular autoantigens, studies using monoclonal antibodies $(\mathrm{mAb})$ show not all antibodies in the polyclonal response are pathogenic. Differences depend on Fab-mediated diversity in epitope specificity, Fc-mediated effects based on immunoglobulin (Ig) class and subclass, activation of complement, and the milieu in which the reaction occurs. These autoantibodies often occur in organ-specific AID and this review illustrates their pathogenic and highly specific effects. The role of autoantibodies associated with intracellular antigens is less clear. In vitro they may inhibit or adversely affect well-defined intracellular biochemical pathways, yet, in vivo they are separated from their autoantigens by multiple cellular barriers. Recent evidence that Ig can traverse cell membranes, interact with intracellular proteins, and induce apoptosis has provided new evidence for a pathogenic role for such autoantibodies. An understanding of how autoantibodies behave in the polyclonal response and their role in pathogenesis of AID may help identify populations of culprit B-cells and selection of treatments that suppress or eliminate them.
\end{abstract}

Keywords: autoimmune disease; monoclonal antibody; immunoglobulin; epitopes; Fc receptors; intracellular antigens; autoantibodies 


\section{Introduction}

The first description of a pathogenic autoantibody by Donath and Landsteiner in 1904 [1] was a landmark discovery in the history of clinical medicine. For the second half of the 19th century clinicians had grappled with the definition of a condition that was characterized by "paroxysms" induced by cold and followed by hemoglobinuria. Typically, but not exclusively, these episodes occurred in subjects with syphilis. The "paroxysm" preceding hemoglobinuria varied in presentation ranging from absence of symptoms to severe backache, abdominal cramps, headache, pyrexia and, in some cases, acute anemia despite the absence of erythrocytes in the hemoglobin-stained urine. The episode was given the descriptive term paroxysmal cold hemoglobinuria $(\mathrm{PCH})$ but the etiology remained unknown until the elegant laboratory studies of Landsteiner demonstrated the sequence of immunological events that occurred in the blood of three subjects with PCH under the care of Donath.

Landsteiner showed that the erythrocytes of these subjects when cooled in an iced water-bath, became "sensitized" by a factor in their serum (or plasma). Then, when the temperature was raised to body temperature and heat-labile factors were present in their serum, their erythrocytes underwent lysis liberating hemoglobin. The autohemolysin had all the hallmarks of a pathogenic autoantibody but, in 1904, little was known about the nature of antibodies, let alone about heat-labile factors in serum.

Autoimmunity was first identified as a cause of disease based on the recognition of self-reactive autoantibodies in the sera of patients. In these early studies, the autoantigens were not well defined and antibodies were considered in terms of reactivity with whole cells, cell extracts or relatively impure antigen, and disease was attributed to these autoantibodies. The first detailed descriptions of experimental induction of autoantibodies, presumed to be pathogenic, were those of Rose and Witebsky [2] who produced autoimmune thyroiditis in rabbits with extracts of thyroid glands. Subsequently similar autoantibodies were demonstrated in the comparable human disease, Hashimoto's thyroiditis [3].

During the latter half of the 20th century many diseases were identified as autoimmune, poorly understood groups containing such diseases were reclassified and immunosuppression became a standard method of treating the chronic inflammation of autoimmunity. Hand in hand with these advances was the discovery that antibodies, although an integral part of the immune system, were not the only means of immunological defense and the immune system was, in fact, a vast and complex network of cells, cytokines and regulatory mechanisms adapted to maintain an optimal state of health in a hostile environment. Although autoantibodies have revolutionized the diagnosis of autoimmune diseases their role in pathogenesis has not always been obvious. Many of apparently unrelated specificities cluster within particular diseases and whilst their association with a disease is undeniable their role in pathogenesis is unclear.

As a template for nominating pathogenic autoantibodies, in this review we sought irrefutable evidence for their pathogenicity in a range of autoimmune diseases, examined the mode of action of antibodies within the polyclonal response, and then scrutinized the role of a number of pathogenic autoantibodies in diseases representative of the entire spectrum of autoimmune diseases. 


\section{Evidence for Pathogenicity}

Various techniques have been used to examine the pathogenicity of autoantibodies (Table 1). The most convincing evidence comes from the development of disease as a result of the direct transfer of autoantibodies. In a minority of autoimmune diseases this occurs by transplacental transfer of immunoglobulin $\mathrm{G}(\mathrm{IgG})$ from an affected mother. The effect of the maternal pathogenic autoantibody on the fetus can range from death in utero to transient disease, with recovery as the parental IgG declines in the neonate.

Table 1. Examples of pathogenic autoantibodies.

\begin{tabular}{|c|c|c|c|c|c|c|c|c|}
\hline \multirow[t]{2}{*}{ Autoantigen } & \multirow[t]{2}{*}{ Disease } & \multicolumn{4}{|c|}{ Induction of Disease by Autoantibody } & \multirow{2}{*}{$\begin{array}{l}\text { In Vitro } \\
\text { Effects }\end{array}$} & \multirow{2}{*}{$\begin{array}{c}\text { B Cell } \\
\text { Depletion } \\
\text { (Rituximab) }\end{array}$} & \multirow{2}{*}{$\begin{array}{c}\text { Plasmapheresis } \\
\text { Plasma } \\
\text { Exchange/IvIg }\end{array}$} \\
\hline & & $\begin{array}{c}\text { Transplacental } \\
\text { Transfer }\end{array}$ & $\begin{array}{c}\text { Human to } \\
\text { Human }\end{array}$ & $\begin{array}{c}\text { Human to } \\
\text { Animal }\end{array}$ & $\begin{array}{c}\text { Animal to } \\
\text { Animal }\end{array}$ & & & \\
\hline Erythrocytes & $\begin{array}{c}\text { Autoimmune } \\
\text { hemolytic anemia }\end{array}$ & yes [4] & & & yes [5] & & & \\
\hline Platelets & $\begin{array}{c}\text { Autoimmune } \\
\text { thrombocytopenic } \\
\text { purpura }\end{array}$ & yes [6] & yes [7] & & & & yes $[8]$ & \\
\hline $\begin{array}{l}\text { Desmogleins } \\
\text { Dsg3, Dsg1 }\end{array}$ & $\begin{array}{l}\text { Pemphigus vulgaris } \\
\text { Pemphigus foliaceus }\end{array}$ & yes [9-13] & & yes $[14,15]$ & yes $[16,17]$ & yes $[18]$ & yes [19] & IvIg [20] \\
\hline $\begin{array}{c}\text { BP180/ } \\
\text { collagen XVII }\end{array}$ & $\begin{array}{l}\text { Bullous pemphigoid } \\
\text { Herpes gestationis }\end{array}$ & yes $[21,22]$ & & $\begin{array}{c}\text { no [23] } \\
\text { antigen differs }\end{array}$ & yes [24-27] & $\begin{array}{c}\text { yes [28] } \\
\text { Requires } \\
\text { neutrophils }\end{array}$ & & $\begin{array}{l}\text { yes [29] } \\
\text { IvIg [20] }\end{array}$ \\
\hline Collagen VII & $\begin{array}{c}\text { Epidermolysis } \\
\text { bullosa acquisita }\end{array}$ & & & $\begin{array}{l}\text { yes [30] limited } \\
\text { cross-reactivity }\end{array}$ & yes [31] & $\begin{array}{c}\text { yes [32] } \\
\text { Requires } \\
\text { neutrophils }\end{array}$ & & $\begin{array}{l}\text { yes [33] } \\
\text { IvIg [20] }\end{array}$ \\
\hline $\begin{array}{c}\text { TSH receptor- } \\
\text { stimulatory-blocking }\end{array}$ & Graves' disease & $\begin{array}{c}\text { yes }[34] \\
\text { yes }[35,36]\end{array}$ & yes [37] & & & & & \\
\hline $\begin{array}{l}\text { Intrinsic factor } \\
\mathrm{H}^{+} / \mathrm{K}^{+} \text {ATPase } \\
\end{array}$ & $\begin{array}{c}\text { Autoimmune } \\
\text { gastritis } \\
\end{array}$ & & & yes [38] & & yes [39] & & \\
\hline $\begin{array}{c}\text { M3 muscarinic } \\
\text { receptor }\end{array}$ & Sjögren's syndrome & & & yes $[40,41]$ & & & & $\operatorname{IvIg}[42,43]$ \\
\hline $\begin{array}{l}\text { Acetylcholine } \\
\text { receptors }\end{array}$ & Myasthenia gravis & yes $[44,45]$ & & yes $[46,47]$ & yes [48] & & yes [49] & yes $[50,51]$ \\
\hline $\begin{array}{l}\text { Presynaptic voltage- } \\
\text { gated } \mathrm{Ca}^{++} \text {channels }\end{array}$ & $\begin{array}{c}\text { Lambert Eaton } \\
\text { Syndrome }\end{array}$ & yes [52] & & yes [53-55] & & & & yes [51] \\
\hline Collagen II & Rheumatoid arthritis & & & yes [56] & yes [57] & yes [58-62] & yes [63] & $\begin{array}{c}\text { yes [64] } \\
\text { Limited efficacy }\end{array}$ \\
\hline
\end{tabular}

Experimentally, pathogenicity has been tested by examining the effects of short-term infusion of autoantibodies, either to human subjects $[7,37,65]$ or to animals, usually mice (Table 1 ). In these cross-species transfers, the amount of antibody and duration of infusion has been limited, and clear evidence for pathogenic effects has been confined to transfer of autoantibodies reactive with cell-surface antigens, including cell adhesion molecules [14], receptors and ion channels [46,53,66], or components of the extracellular matrix, particularly collagens [31,57,67]. 
Studies of direct transfer of antibodies have been supplemented by the development of animal models of diseases. For a number of autoimmune diseases, there are spontaneously occurring models, but although these provide essential insights into the genetics and processes pertaining to the development of autoimmunity, their complexity including T-cell interactions limit their utility for examining the pathogenicity of autoantibodies. However, useful models that are T-cell independent have been developed either by transfer of monoclonal antibodies from an immunized animal, as has been done in collagen antibody induced arthritis (CAIA) [57], or, where human autoantibodies are unreactive with the mouse equivalent, by transfusing mice with anti-mouse antibodies derived by immunizing another species with mouse antigen [27,31]. In these cross-species transfers, the amount of antibody and duration has been limited, and gross pathogenic effects are often difficult to observe, but a mouse model of pemphigus vulgaris has been developed in which there is continuing exposure to autoantibodies without concomitant $\mathrm{T}$ cell responses by injecting the mouse desmoglein Dsg3 into Dsg $3^{-/}$mice, then transferring splenocytes from those mice into Rag- $1^{-/}$immunodeficient mice that then continue to produce autoantibodies [16].

Evidence for pathogenicity has also come from clinical improvement after removal of autoantibodies by plasma exchange or plasmapheresis, or from B cell depletion with drugs such as Rituximab (anti-CD20), or with intravenous immunoglobulin (IVIG), for which the mode of action is still unclear, but may involve replacement of anti-idiotype antibodies.

\section{Mode of Action}

In the normal immune system, the production of antibodies is triggered by foreign proteins, microorganisms or toxins, and antibodies are responsible for their elimination, both by direct inactivation, and by activating secondary effector cells. Antibody responses can be categorised in terms of a primary reaction involving the antigen-binding site (paratope) of the Fab region of the antibody with the specific epitope on the cognate antigen combined with secondary effector functions, both complement-mediated and cellular, through interactions of the constant regions of the heavy chain, particularly the Fc. Similar events occur also in autoimmune responses.

\subsection{Fab-Mediated Effects}

Binding of $\mathrm{F}(\mathrm{ab})_{2}$, monomeric Fab, or single chain variable domain fragments $(\mathrm{ScV})$ is readily demonstrable for most antigens in vitro, but evidence of direct pathogenicity of Fab has been demonstrated for relatively few autoantigens, as such tests require not only a source of relatively pure antibody to prepare the Fab, but also an appropriate functional assay to test the effect of binding. The antigen must be accessible to Fab binding, and the binding must alter some biological function of the exposed antigen, whether by competing with interactions with other proteins, or by blocking a cellular function. For example, to show the pathogenic effects of $\mathrm{F}(\mathrm{ab})_{2}$, Fab, or ScV from antibodies to desmoglein in pemphigus vulgaris, pathogenicity was assessed by the development of skin blisters following injection into newborn mice [68-71]. In another functional assay, electron microscopy was required to show that $\mathrm{F}(\mathrm{ab})_{2}$ from a monoclonal antibody to collagen II inhibited normal collagen fibril formation in chondrocyte cultures [59]. 
$\mathrm{F}(\mathrm{ab})$-mediated functional effects have been shown for autoantibodies to a range of surface receptors and ion channels. For some, such as autoantibodies to the M3 muscarinic receptor where monomeric $\mathrm{F}(\mathrm{ab})$ is inhibitory, these may block cell function directly, but for others, where functional effects are seen with $\mathrm{F}(\mathrm{ab})_{2}$, but not $\mathrm{Fab}$ or $\mathrm{ScV}$, changes have been related to loss of surface receptors following cross-linking and internalization of surface receptors with the divalent $F(a b)_{2}$ [72-75].

Less directly, F(ab)-mediated effects could be modified by the somatic hypermutation that occurs during affinity maturation. The paratope is formed from three hypervariable complementarity determining regions (CDRs) that are separated by four framework regions which have more stable amino acid sequences, and these hypervariable regions undergo considerable somatic mutagenesis during affinity maturation [76,77]. As not all the amino acids in the CDRs for any particular antibody are involved in antigen binding, somatic hypermutation can occur not only in residues within the paratope, but also in adjacent areas not originally involved in antibody binding. Such mutations could not only change the affinity of binding, but also modify the epitope recognised, or change the properties of the antibody, and may affect interactions with anti-idiotypic antibodies [78].

\subsection{Fc-Mediated Effects}

The structure of the paratope of the Fab region defines the specificity and affinity with which antibodies bind with their cognate antigen. Factors that amplify the effect do not depend on the antigenic specificity, but on the properties of the immunoglobulin class or subclass. These secondary effects depend on the structure of the Fc-region, which defines the Ig isotype or subclass of the antibody, and plays a critical role in amplifying the effect of an antigen-antibody interaction by complement activation, or binding to Fc-receptor (FcR)-bearing effector cells, such as monocytes, macrophages, dendritic cells, neutrophils, mast cells, and natural killer cells. Four Fc $\gamma$ receptors have been described that bind $\operatorname{IgG}$ subclasses with differing affinities, and have different functions (Table 2), and Fc receptors have been described that bind to each of the immunoglobulin classes. The FcaR1 (CD 89) binds IgA, Fc $\alpha / \mu$ binds IgM and also IgA but with lower affinity, and two Fee receptors bind IgE.

Table 2. Properties of human IgG subclasses.

\begin{tabular}{|c|c|c|c|c|c|c|}
\hline & & & IgG1 & IgG2 & IgG3 & IgG4 \\
\hline Proportion of total IgG & & & $66 \%$ & $23 \%$ & $7 \%$ & $4 \%$ \\
\hline Crosses placenta [79] & & & ++ & \pm & + & + \\
\hline Complement activation & & & ++ & + & +++ & - \\
\hline Clq binding and activation [80] & & & + & - & +++ & - \\
\hline Complement-mediated hemolysis [80] & & & +++++ & - & ++ & - \\
\hline C4 activation [80] & & & +++++ & - & ++ & - \\
\hline Binding to Fc $\gamma$ Receptors $[81,82]$ & & Major Function & & Binding Affir & ties $\left(\mathbf{M}^{-1}\right)$ & \\
\hline $\begin{array}{c}\text { Fc } \gamma \text { R1 (CD64) "high affinity receptor" monocytes, } \\
\text { macrophages, neutrophils, dendritic cells }\end{array}$ & Fc $\gamma$ R1 & Activation & $6 \times 10^{7}$ & No binding & $6 \times 10^{7}$ & $3 \times 10^{7}$ \\
\hline \multirow{3}{*}{$\begin{array}{l}\text { Fc } \gamma \text { RII (CD32) "low affinity receptor" monocytes, } \\
\text { macrophages, neutrophils, eosinophils, platelets, } \\
\text { B cells, dendritic cells, endothelial cells }\end{array}$} & Fc $\gamma$ RIIA & Activation & $5 \times 10^{6}$ & $4 \times 10^{5}$ & $9 \times 10^{5}$ & $2 \times 10^{5}$ \\
\hline & Fc $\gamma$ RIIB & Inhibition & $1 \times 10^{5}$ & $2 \times 10^{4}$ & $2 \times 10^{5}$ & $2 \times 10^{5}$ \\
\hline & Fc $\gamma$ RIIC & Activation & $1 \times 10^{5}$ & $2 \times 10^{4}$ & $2 \times 10^{5}$ & $2 \times 10^{5}$ \\
\hline $\begin{array}{l}\text { Fcy RIIIA (CD16) "low affinity receptor" neutrophils, } \\
\text { eosinophils, macrophages, NK cells, subsets of T cells }\end{array}$ & Fc $\gamma$ RIIIA & Activation & $2 \times 10^{5}$ & $7 \times 10^{4}$ & $1 \times 10^{7}$ & $2 \times 10^{5}$ \\
\hline
\end{tabular}

Bold: High affinity. 
In the adaptive immune response, complement activation is initiated via the classical pathway by $\mathrm{C} 1 \mathrm{q}$ binding with the Fc region of antibodies in immune complexes [83]. Both IgM and IgG antibodies activate complement, IgM more efficiently, and there are differences in the activity of the IgG subclasses, both in initial binding with $\mathrm{Clq}$, but also in effects in activating later steps in the complement pathway (Table 2). Also, binding of the Fc region of the Ig to the extracellular parts of the $\alpha$ chains of the FcR leads to cross-linking and activation of tyrosine kinases interacting with intracellular FcR domains, stimulating phagocytosis, degranulation and release of cytokines and inflammatory mediators, and antibody-dependent cellular cytotoxicity. Different FcRs are expressed by different cell types, with different biological activities that are modulated by aggregation by multivalent antigen-antibody complexes. Most cells express several FcRs, and different FcRs can generate different signals to a single cell. In addition, different immunoglobulin classes, and particularly IgG subclasses, bind to different FcRs (Table 2). Together, these interactions allow considerable diversity of responses to any antigen. Both stimulatory and inhibitory Fc $\gamma \mathrm{R}$ receptors can occur and there is a complex interaction between the effects of Fc $\gamma \mathrm{R}$ and complement [84,85]. As different Ig subclasses differ in their capacity to activate complement, and bind with differing affinity to different Fc $\gamma$ Rs, autoantibodies can differ not only in their antigenic specificity, but also in secondary pathogenic effects related to their immunoglobulin subclass.

The importance of Ig classes and subclasses in determining the pathogenicity of autoantibodies has been shown in studies of murine autoimmune hemolytic anemia, induced by monoclonal antibodies (mAbs) to mouse red blood cells from hybridomas from adult anemic NZB mice. The mAbs were pathogenic in BALB/c mice, and caused marked anemia with a single injection. The anemia resulted from sequestration of agglutinated cells in spleens and liver, with erythrophagocytosis by Kuppfer cells in the liver, and not from complement-dependent hemolysis [5]. Four IgG class-switch variants of two of these $\mathrm{mAb}$ were derived that retained their epitope specificity. Their use to induce haemolytic anemia by injection into $\mathrm{BALB} / \mathrm{c}$ mice demonstrated clearly that there were major differences in pathogenicity according to the IgG subclass of the antibody. The extent of anemia that developed following a single injection did not depend on the epitopes recognised, but correlated with Fc-receptor dependent phagocytosis and complement activation [86-89].

Although most Fc-receptors are located on immune effector cells, Fc receptors can occur on other cells. For example, various Fc $\gamma$ receptors occur in the brain, on microglia, astrocytes, oligodendrocytes and neurons, where they may facilitate immunoglobulin uptake and transport to the cell body [90,91]. Other specialised Fc-receptors transport immunoglobulins across epithelial cells to their main site of action. The polyimmunogobulin receptor pIgR is an Fc-receptor that facilitates the secretion of soluble polymeric isoforms of IgA and IgM, and is involved in the transcytosis and secretion of antibodies at mucosal surfaces [92]. The neonatal Fc-receptor ( $\mathrm{FcnR}$ ), facilitates transfer of maternal IgG to the fetus across the placenta [93,94], but in adult life it occurs in lungs, kidneys and other organs [95]. Fc-mediated transport into cells with various receptors can occur, and this could provide a means of autoantibodies accessing intracellular antigens (see Section 5).

\subsection{Immune Complex Mediated Effects}

In the examples above, in considering Fc-mediated secondary effects, the modes of action have assumed specific antibodies defined by their reactivity with particular autoantigens. However, tissue-damaging 
effects can also be associated with Fc-mediated effects involving immune complexes that may not be as readily defined as antigen-specific. Soluble immune complexes associated with a variety of antigens have been particularly associated with the multi-system autoimmune diseases such as SLE, Sjögren's syndrome and rheumatoid arthritis, particularly those associated with various non-tissue-specific autoantibodies, and in these cases damage has been attributed to such immune complex-mediated effects. The secondary processes described above, associated with specific autoantigens are also relevant in these cases. Complement binding occurs as part of the normal physiological process, with sustained production of activated complement, and recruitment of phagocytes with cell-mediated tissue damage involving activated basophils and neutrophils.

Although each antibody involved in such complexes would be binding to a specific antigen, no single antigen has been associated with immune complex formation in any of these diseases. Immune complexes may be detectable in various tissues, and multiple autoantigens could contribute. For example, autoantibodies of multiple different specificities have been eluted from the immune deposits in glomeruli of patients with SLE and lupus nephritis, including autoantibodies to dsDNA, histones, C1q, Sm, SSA (Ro) and SSB (La) that are not specific to glomeruli, and are also present in the serum [96-98].

\subsection{Therapies that Modify Fc-Mediated Secondary Effects of Antibodies}

Although discussion of therapies for B-cell mediated pathogenic effects are often confined to those that directly impact on autoantibody levels, such as anti-CD20 (Rituximab), or plasmapheresis, it should be noted that immunotherapies that are directed at inflammation also directly impact on the Fc-mediated effects of autoantibodies. A variety of anti-inflammatory agents are routinely used. These include aspirin and other nonsteroidal anti-inflammatories (NSAIDs) that are inhibitors of cyclooxygenase (COX) enzymes COX-1 and COX-2, the enzymes that synthesize prostaglandins, reducing pain associated with inflammation, and glucocorticoids used for reducing inflammation. Also, new "biologics" such as anticytokine therapies reduce the activity of specific cytokines or their receptors, limiting the activation of monocytes, macrophages, and other effector cells [99]. An example is the success of drugs targeting the production of TNF by inflammatory cells in rheumatoid arthritis: these include Infliximab, Etanercept, Adalimumab, as first line drugs for treatment of patients with refractory rheumatoid arthritis [100].

\section{Pathogenic Effects of Autoantibodies}

As stated earlier, clear evidence for pathogenic effects of autoantibodies has been confined almost exclusively to those antibodies reactive with receptors on cell surfaces, adhesion molecules and ion channels or secreted products of cells. This section selects examples of such pathogenic autoantibodies and describes their injurious effects in the setting of disease.

\subsection{Autoantibodies to Desmosomes and Hemidesmosomes}

Autoantibodies to these cell-attachment proteins have been implicated in the development of bullous skin diseases characterized by epithelial separation (acantholysis) of mucous membranes, or mucous membranes and skin. These are represented by two major groups of autoimmune diseases, the pemphigus and pemphigoid syndromes (Table 1). 


\subsubsection{The Pemphigus Syndromes}

The most direct evidence for pathogenic effects of Fab binding has come from studies of pemphigus vulgaris (PV), including paraneoplastic pemphigus associated with underlying neoplasms [101], and pemphigus foliaceus (PF), characterized by intra-epidermal blistering of skin and mucosa, with epidermal cell-to-cell detachment, and associated autoantibodies to desmogleins, the cadherin-type cell-cell adhesion molecules in desmosomes. In these diseases, there is clear evidence that the damage is Fab-mediated, that only some autoantibodies are pathogenic, and damage can be correlated with epitopes recognised. In PV, the acantholysis is mainly in the superbasilar region of the epithelial layer, and is strongly associated with autoantibodies to Dsg-3, when restricted to the mucous membranes. However, when the disease also affects skin, there are antibodies to Dsg-3 and Dsg-1. By contrast, autoantibodies in PF tend to be subcorneal, limited to the skin, and associated with autoantibodies to Dsg-1.

Each of these diseases can be reproduced by antibody transfer. In mothers with pemphigus there is placental transfer of autoantibody to the fetus, leading to transient PV in the neonate [9-11]. Both PV and PF can also be transferred to neonatal mice using IgG from patients [14,15,31,69]. In these studies, pathogenicity has been assessed by the development of skin blisters, but the effects can also be demonstrated in vitro using cultured human keratinocytes [18]. The effect was Fab-mediated, with no requirement for Fc interactions, as passive transfer to mice occurred using $\mathrm{F}(\mathrm{ab}) 2$, Fab or scFv [31,69-71]. Ultrastructural studies in mice showed that antibody penetrated desmosomal plaques, blocking cell-cell interactions within the desmosomes and resulting in basal cell keratinocyte separation and development of a "tombstone-like" appearance, with split desmosomes with anti-Dsg3 IgG bound extracellularly [102]. The process occurred rapidly, within hours, without inflammation and appeared to be a direct result of antibody binding [103]. These results are consistent with the observation that in human PV there is rarely any inflammation in the lesions, no requirement for complement, and autoantibodies in the human diseases are predominantly IgG4.

Epitope analysis performed using polyclonal antibodies [104,105], human mAb [106,107] and panels of human anti-Dsg scFv isolated by phage display from a patient with active acute mucocutaneous PV [70] have shown that antibodies bind to all regions of the extracellular domains of Dsg1 and Dsg3. Both pathogenic and non-pathogenic $\mathrm{mAb}$ and $\mathrm{Scv}$ have been isolated, and there is an immunodominant epitope region at the $\mathrm{N}$-terminus that correlated with pathogenicity. The epitope(s) recognised in polyclonal sera are predominantly conformational and stabilised by calcium [108], but although most Scv isolated reacted similarly, there was variability, both in capacity to react by immunoblotting, and to show cross-reactivity between Dsg1 and Dsg3. Genetic analysis of these Scvs showed restricted patterns of heavy and light chain gene usage that differed according to the Dsg recognised.

\subsubsection{The Pemphigoid Syndromes}

These are blistering skin diseases in which the site of the lesion is at the dermal-epidermal junction, and include bullous pemphigoid (BP), pemphigoid gestationis (PG) and epidermolysis bullosa acquisita (EBA). BP is characterized by skin lesions appearing as areas of urticaria that develop into large bulla, with separation of the epidermis from the dermis, with an intense infiltration of inflammatory cells in the underlying dermis, and destruction of components of the hemidesmosome and extracellular 
matrix [26]. PG also known as herpes gestationis, is a non-viral variant of BP that occurs in early pregnancy or post-partum and can result in transient neonatal PG [21,22]. In BP and PG, autoantibodies are directed to hemidesmosomes that are cellular structures involved in anchoring keratinocytes to the basement membrane, and the major autoantigen is BP180, a transmembrane protein belonging to the collagen family, also known as collagen XVII. The extracellular domain of BP180 contains 15 collagen domains, interrupted by 16 non-collagen (NC) sequences, and the membrane-proximal $\mathrm{NC}$ domain NC16A contains multiple epitopes recognised by sera from patients with BP [109-112].

Epidermolysis bullosa acquisita (EBA) is another subepithelial blistering disease in which blisters are formed as a result of detachment of the epidermis from the sub-basal lamina densa, often in areas of trauma. It is associated with autoantibodies to the N-terminal non-collagenous domain (NC1) of type VII collagen that is the major component of anchoring fibrils in the basement membrane. It has similarities to dystrophic epidermolysis bullosa in which there is a hereditary defect in the gene that encodes type VII collagen, and to BP, although the degree of associated inflammation is more variable, and may be less than that seen in BP [113].

As the human autoantibodies to both BP180 (collagen XVII) and collagen VII react poorly with the animal antigens due to sequence differences, there is limited evidence for direct passive transfer of either BP or EBA to animals by human IgG [23,31,114,115]. However, in each case, passive transfer has been achieved using antibodies specific to the pathogenic epitope region of the recipient animal. Thus, although autoantibodies to human NC16A do not react with NC16A from other species, mouse models of BP have been derived in which passive transfer of antibodies from rabbits or sheep immunized with recombinant mouse NC16A induce blistering skin lesions in neonatal or adult mice [24,27]. Similarly, an animal model of EBA was developed using passive transfer of rabbit antibodies to the mouse NC1 domain [31].

The mechanisms of damage in BP or in EBA are more complex than those in PV or PF, requiring interactions through the $\mathrm{Fc}$ region of the molecule to trigger interactions with the innate immune system, involving complement and inflammatory cells. In vitro in both diseases, human autoantibodies induced epidermal-dermal separation in cryosections of human skin that did not take place with $\mathrm{F}(\mathrm{ab})_{2}$, and the process required the addition of neutrophils [31,32]. Experiments in vivo have confirmed these results, and have demonstrated the role of neutrophil elastase and of mast cells in these processes $[25,26]$.

Notably, in both the pemphigus and pemphigoid syndromes, the epitopes recognised and IgG subclasses of autoantibodies are important for pathogenesis. Both pathogenic and non-pathogenic autoantibodies can occur, and pathogenic autoantibodies can react with various subregions within an epitope region, giving an additive effect when several different autoantibodies are combined $[16,17,116]$. Also, the IgG subclass is important. None of the autoantibody responses are restricted to a single subclass, and the complexity of the antibody responses has been extensively reviewed [117]. However, IgG4 which has limited capacity to activate Fc receptors, and does not activate complement is particularly associated with PV [118,119]. By contrast, both IgG4 and IgG1 are associated with BP, and IgG1 has been associated with the acute phase, whereas IgG4 was more associated with remission [120]. 


\subsection{Autoantibodies to $\mathrm{H}^{+} / \mathrm{K}^{+}$ATPase and Gastric Intrinsic Factor}

Autoimmune gastritis is a chronic inflammatory condition of the parietal cell-rich area of the stomach that may, over a period of 20-30 years, lead to gastric atrophy associated with malabsorption of cobalamin (vitamin B12), and development of pernicious anemia. The two autoantibodies implicated in the autoimmune process react with gastric intrinsic factor that is synthesized by the parietal cell, and with $\mathrm{H}^{+} / \mathrm{K}^{+}$ATPase that is also synthesized by the parietal cell and is responsible for the acidification of the gastric juice [121,122].

Gastric intrinsic factor (IF) is a glycoprotein that is required for absorption of cobalamin in the small intestine, and two autoantibodies of different specificities are reactive with it. One is a blocking antibody reactive with the receptor site for the binding of cobalamin to intrinsic factor [123], and the second is reactive with a site remote from the cobalamin binding site, and does not interfere with the formation of the intrinsic factor-cobalamin complex, but blocks the complex from binding to the cubam receptor in the ileum $[124,125]$. Antibodies have been demonstrated in gastric juice in complex with intrinsic factor $[125,126]$, and their presence could explain the malabsorption of cobalamin and development of pernicious anemia. Normally a large excess of intrinsic factor is secreted, and is available for binding with cobalamin. Any antibody present would readily dissociate in the acidic milieu. However, in the achlorhydric gastric juice of autoimmune gastritis binding is increased $(100 \%$ at $\mathrm{pH} 7.5 \mathrm{vs.} 30 \%$ at $\mathrm{pH}$ 3.2 at $90 \mathrm{~s}$ ) [126], thus reducing the availability of cobalamin for absorption in the ileum where the second antibody inhibits binding to the cubam receptor.

The other major parietal cell autoantigen has been identified as $\mathrm{H}^{+} / \mathrm{K}^{+}$ATPase, an integral membrane proton pump. Parietal cell antibodies have been shown to deplete $\mathrm{H}^{+} / \mathrm{K}^{+}$ATPase activity from parietal cell membranes [39], and their presence is associated with raised levels of gastrin and hypochlorhydria [127] favouring the intrinsic factor antibody-cobalamin reaction. In rats, repeated infusions of IgG from sera of subjects with pernicious anemia with gastric atrophy and parietal cell antibodies resulted in thinning of the gastric mucosa, reduction in parietal cell mass and hypochlorhydria [38]. Furthermore, in women with antibodies to $\mathrm{H}^{+} / \mathrm{K}^{+}$ATPase, IgG was demonstrated on the surface and within parietal cells that showed no sign of atrophy of the cell or the oxyntic gland containing them suggesting that antibodies have access to $\mathrm{H}^{+} / \mathrm{K}^{+}$ATPase [127] and may be involved pathogenetically in the failure of the proton pump.

Although these autoantibodies are associated with the development of autoimmune gastritis, and are predictive of the cobalamin malabsorption that leads to the development of pernicious anemia [128], it remains generally accepted that experimental autoimmune gastritis is primarily a T-cell mediated disease $[129,130]$. Nonetheless, taken together, these two autoantibody populations could explain the symptoms and progression of disease in autoimmune gastritis. Atrophy of parietal cells, and loss of function associated with parietal cell antibodies would establish conditions for depletion of intrinsic factor, both directly by lack of secretion, and also by creating conditions within the stomach that are favourable to antibody binding.

\subsection{Autoantibodies to Collagen}

Rheumatoid arthritis illustrates the complexity of pathogenic antibody responses in a single disease, in which the secondary pathogenic effects associated with Fc binding play a major role, but may be 
modified by Fab epitope reactivity. It is generally considered to be immune complex-mediated. The primary target of the disease is the articular joint, with cartilage destruction, bone erosion, and an inflammatory infiltration within the synovium. It is characterized by three populations of autoantibodies: antibodies to the Fc-region of IgG (rheumatoid factor, RF), antibodies to citrullinated proteins (ACPA), and antibodies to type II collagen (CII). Of these, the presence of RF and ACPA predict more severe erosive disease [131], but CII is the only joint specific antigen, and autoantibodies to CII are frequent early in the disease [132-135].

A similar arthritis, collagen antibody induced arthritis (CAIA) can be transferred passively to naïve mice using CII-reactive mouse serum [136], human serum [56], or mouse mAb to CII [57,67]. As CAIA is not MHC-restricted, and can be induced in mice lacking an adaptive immune system, it is an excellent model to examine the effector role of autoantibodies in the induction of arthritis [57]. The arthritogenic $\mathrm{mAbs}$ to CII are reactive with conformational epitopes on the CII triple helix, several of which are shared with human antibodies (Table 3).

The pathogenic mAbs used to induce CAIA bind to the surface of the cartilage and C3 is deposited at the same site $[137,138]$. Histologically, there is inflammation associated with heavy infiltrations of neutrophils along with bone and cartilage erosion, pannus formation, and fibrin deposition [57]. The inflammation that results can be considered as a secondary effect of the development of immune complexes within the cartilage, in a process that requires proinflammatory cytokines, particularly TNF and IL1 $\beta$, Fc $\gamma$ receptors, and complement activation and C5a [57,138-142]. Neutrophils are essential not only for arthritis development, but also for its maintenance [140]. C5a is a potent neutrophil chemoattractant, and mice that lack C5a receptor do not develop CAIA [143]. These processes are similar to those seen in other animal models of immune complex mediated arthritis, and are consistent with changes seen in a subset of patients with human RA who have high levels of antibodies to CII [144-146]. It is likely that immune complexes containing RF or ACPA exert pathogenic effects within the joint by similar mechanisms.

Table 3. Mouse mAbs to CII used for mapping and defining epitopes in collagen antibody induced arthritis (CAIA) ${ }^{1}$.

\begin{tabular}{|c|c|c|c|c|}
\hline MAb & CIIC1 & UL1 & M2139 & CIIF4 \\
\hline Epitope location on CII (amino acids) [147] & $356-369$ & $494-504$ & $551-564$ & $926-936$ \\
\hline Sequence $[147,148]$ & ARGLT & LVGPRGERGFP & MPGERRGAAGIAGPK & HRGFT \\
\hline Possible binding site on collagen & Chondroadherin & Integrin & Collagen IX/integrin & Stromelysin \\
\hline Effects on fibrillogenesis in vitro [149] & Inhibition & Not tested & Inhibition & No effect \\
\hline \multicolumn{5}{|l|}{ Effects in chondrocyte cultures $[58,59,62]$} \\
\hline Chondrocytes & Normal & Vacuolated & Pleiomorphic & Normal \\
\hline Proteoglycan loss & Yes & Yes & Yes & No \\
\hline Collagen denaturation & Yes & Yes & Yes & No \\
\hline Collagen loss & Yes & Yes & Yes & No \\
\hline
\end{tabular}


In addition to these changes, autoantibodies to CII have effects that differ according to the epitope specificity of the $\mathrm{mAb}$, and although various $\mathrm{mAbs}$ can induce arthritis when injected at low doses [137], enhancement by a large dose of a single $\mathrm{mAb}$ does not induce the severe arthritis that can be induced by combinations of $\mathrm{mAb}$ with different epitope specificities $[151,152]$. There are striking differences in the induction of CAIA by mAb recognising different epitopes that cannot be related to the affinity or the subclass of the antibody [151,152] (Table 3). Antibodies reactive with the epitope recognised by mAb UL1 are associated with chronic, relapsing arthritis in mice, rats and humans [62,153], whereas another $\mathrm{mAb}$ CIIF4, reactive with the F4 epitope on CII, is non-arthritogenic in mice, and inhibits CAIA development when given with known arthritogenic mAb [154]. Antibodies reactive with the F4 epitope have been associated with osteoarthritis in humans [154].

Several mAb have been shown to modify cartilage synthesis or breakdown in vitro, in the absence of immune cells or complement. Two arthritogenic mAb, CIIC1 and M2139 inhibited fibrillogenesis of CII in vitro, whereas the non-arthritogenic mAb CIIF4 did not [149]. The arthritogenic mAb, CIIC1, M2139 and UL1 also impaired cartilage formation by cultured chondrocytes, causing morphological changes to the cells, or disorganization of the cartilage fibrils that differed according to the $\mathrm{mAb}[58,59,62]$, as well as proteoglycan loss and cartilage damage in cartilage explant cultures $[60,62]$. In these cultures, $F(a b)_{2}$ was as potent as the mAb itself [60], and the location of the epitopes for these arthritogenic $\mathrm{mAb}$ suggested that the degradative effects observed were related to interference with interactions between CII and other essential matrix components. Viable chondrocytes appeared to play a protective role, as the matrix damage was substantially increased when chondrocytes were pre-killed by freeze-thawing the cartilage before culture [61]. Interestingly, the non-arthritogenic mAb CIIF4 had no apparent effects when tested in the cultures alone, but the addition of CIIF4 to cartilage explants cultured with arthritogenic $\mathrm{mAb}$ had a clear and unexplained protective effect on the cartilage matrix [61].

Notably, this discussion has considered only one potential autoantibody, although it is the one with joint specificity. ACPA are reactive with neo-epitopes found on proteins in which citrulline has been derived by deimination of arginine by peptidyl-arginine-deiminases (PADI), an enzyme found in the inflamed synovium [155,156]. There is an HLA association of RA with HLA-DRB1 genes, particularly HLA-DR4 and DR1 alleles containing a "shared epitope" [157]. One scenario could be that the primary autoantigen that provides the joint specificity is CII, leading to immune complex deposition and low-grade inflammation. Within that milieu, joint antigens are citrullinated by PADI in macrophages in the initial CII-immune complexes. Complement activation in immune complexes has been shown to enhance phagocytosis, antigen presentation and B cell activation [158] and this could lead to increased ACPA production and enhanced immune complex formation. RF may be a secondary effect of enhanced antigenic stimulation, as it can occur in subjects with chronic infections like parasitic infections or in healthy subjects after multiple vaccinations, and may potentiate the inflammation [159]. Consistent with this, is our observation that in early RA, ACPA or RF were rare in the absence of anti-CII, and that the presence of antibodies to CII in the absence of RF or ACPA was associated with a more favourable outcome.

\subsection{Autoantibodies to Muscarinic Receptors}

Sjögren's syndrome is a chronic inflammatory disease, characterized by lymphocytic infiltration of the salivary and lacrimal glands, leading to the characteristic symptoms of a dry mouth and dry eyes and 
it may also affect other exocrine glands [160]. It may occur alone (primary Sjögren's Syndrome, SS), or with other autoimmune diseases (secondary SS). Primary SS is characterized by hypergammaglobulinemia, rheumatoid factor, and autoantibodies to two ribonucleoprotein antigens, SS-A (Ro) and SS-B (La). Of these autoantibodies, anti-La is the most abundant, occurring at high frequency, and constituting up to $10 \%$ of serum $\operatorname{IgG}$ [161]. Secondary SS although sharing the same sicca manifestations of primary SS, does not have the same clinical and genetic features and, serologically, the antibody profile takes on that of the associated disease be it rheumatoid arthritis, SLE or primary biliary cirrhosis for example. The contribution of these antibodies to the development of Sjögren's syndrome is unknown. However, recently there has been increasing evidence that the secretory deficit is related to the presence of a population of autoantibodies that target the M3 muscarinic acetylcholine receptor (M3R) in the salivary glands. M3R mediates cholinergic neurotransmission in tissues innervated by the autonomic nervous system such as salivary and lacrimal glands, blood vessels, the bladder and the gastrointestinal tract, and plays crucial roles in exocrine secretions and in smooth muscle contraction, including gastrointestinal motility.

The first evidence for such autoantibodies came from the observation that $\mathrm{IgG}$ from patients with primary SS caused loss of secretory function of exocrine tissues in the NOD mouse [40], and activated muscarinic acetylcholine receptors of rat parotid gland independent of anti-Ro or anti-La [162]. In a further study using a functional smooth muscle bioassay to demonstrate antibodies to M3R, 5 of 9 patients with primary SS and 6 of 6 patients with SS and rheumatoid arthritis were positive. By contrast, sera from 15 of 16 controls, including healthy individuals, patients with rheumatoid arthritis without sicca, and patients with systemic lupus erythematosus, were negative [163]. More recently, the presence of autoantibodies has been confirmed in both primary and secondary SS using a variety of functional assays based on measurement of contractions in smooth muscle $[41,42,164]$, or of $\mathrm{Ca}^{2+}$ influx in salivary cells [165] and also ELISAs based on peptide antigens [166-168]. The effect is Fab-mediated, and is induced by monovalent Fab, F(ab) $)_{2}$ or IgG [42]. Various epitopes have been mapped on the extracellular loops of the receptor, and antibodies binding to these epitopes may have different effects according to the location of binding [166].

M3R antibodies have also been associated with altered gastrointestinal mobility in Sjogren's syndrome [169]. Functional antibodies that affect parasympathetic neurotransmission could not only lead to altered secretion by exocrine organs such as salivary and lacrimal glands, but also mediate the bladder and gastrointestinal dysfunction in SS by altering the effects of endogenously released acetylcholine on smooth muscle and explain the link between the two clinical entities.

\section{Pathogenic Effects of Autoantibodies to Intracellular Antigens}

The pathogenic autoantibodies that we have considered so far (Table 1) have been reactive with autoantigens that are exposed to the blood and body fluids and are freely available to antibody in the contact medium. By contrast, the intracellular autoantigens may be separated from the extracellular milieu by several membranes. Many are shared by all nucleated cells, and are widely distributed within cells, being located in ribosomes, mitochondria, centromeres, nucleoli, and nuclei, and even on cellular structures present only transiently during cell division. Others may be quite tissue or organ specific such as the autoantibodies associated with paraneoplastic neurological syndromes that target nuclear or 
cytoplasmic intracellular proteins in the brain [170], or the autoantibodies to the enzyme glutamic acid decarboxylase (GAD) that occurs in $\beta$-islet cells in the pancreas and GABA-producing cells in the brain. If the antigen has been identified, functional impairment may have been demonstrated in vitro by autoantibody so the potential pathogenicity of these autoantibodies in vivo cannot be dismissed [171-175].

How autoantibody gains access to intracellular antigens is still unclear. However penetration of cells by autoantibodies has been described for various intracellular antigens, including nuclear antigens RNP [176], Ro and La [177,178] and double-stranded DNA (dsDNA) [179-183], as well as ribosomal $\mathrm{P}$ proteins [184], the E2 subunit of the pyruvate dehydrogenase complex (PDC-E2) located in mitochondria [185], and neuronal and retinal proteins [186,187]. Such penetration has been associated with functional changes that may differ according to the phase of the cell cycle or state of activation of the particular cell $[177,181,188]$. Also antibody has been shown to lead to apoptosis of the transfected cells $[181,186,187,189]$.

The methods of penetration differ for different antibodies. Internalization mediated by binding to Fc-receptors has been described for autoantibodies to nuclear antigens, such as anti-RNP, anti-Ro and anti-La that bind to Fc $\gamma$ receptors [177-179], or the IgA antibodies to PDC-E2 in primary biliary cirrhosis that bind to the polyimmunoglobulin receptor $\mathrm{pIgR}$ for penetration of biliary epithelial cells [185]. Fc-mediated internalization of autoantibodies may be of particular significance in the brain, where Fc receptors are widely distributed in neural tissue, increase during aging, and may be involved in neurological disorders [91,190]. Fc-dependent uptake of IgG has been shown by neurons, particularly Purkinje cells, with accumulation in the cytoplasm and microtubular transport within the cell [90,191-195].

Not all mechanisms for cell penetration depend on binding to Fc-receptors. One method that has been extensively studied for autoantibodies to dsDNA depends on involvement of arginine-rich peptide sequences. Panels of mAbs that react strongly with anti-dsDNA have been derived from the spleens of (NZBxNZW)F1 mice [196]. Although mAbs alone have been shown to enter and accumulate within the nucleus in a few hours, as well as $\mathrm{mAb}$, or $\mathrm{F}(\mathrm{ab})_{2}$ or $\mathrm{F}(\mathrm{ab})$ coupled to biotin, fluorescein or peroxidase, not all anti-dsDNA showed equal cell penetration and translocation. Penetration and translocation were linked to increased lysines and arginines in the complementarity determining regions (CDR) of the antibodies, and peptides corresponding to CDR2 linked to CDR3 of several penetrating mAb were designed that penetrated cells, and could be used as a vector to transport macromolecules[180,196]. Further studies showed that this was associated with electrostatic interactions of arginine residues in the CDR interacting with negatively charged sulphated polysaccharides on the cell surface [183], and arginine-rich cell penetrating peptides are now being investigated as promising tools for precise intracellular drug delivery [197,198].

These arginine-rich cell-penetrating sequences may also contribute to the pathogenicity of anti-dsDNA in the development of lupus nephritis. Anti-dsDNA occur in $50 \%-70 \%$ of patients with SLE, and are strongly associated with lupus nephritis and a rise in titre of anti-dsDNA can be indicative of a flare of disease activity. However, not all anti-dsDNA are pathogenic and not all patients with high levels of anti-dsDNA have lupus nephritis. Statistical analysis of sequences of pathogenic human IgG mAbs to ds-DNA from patients with SLE showed multiple somatic mutations in the variable regions of the antigen, particularly an accumulation of arginines in the CDR that were predicted to interact and enhance binding with dsDNA. This was confirmed by cloning and expressing variant IgG molecules to localise particular arginine residues that were critically sensitive for the ability to bind DNA [199]. 
The apoptosis that may occur following cell penetration by anti-dsDNA and other autoantibodies may also play a role in the pathogenicity of autoantibodies to intracellular antigens. Cellular apoptosis may not only provide a source of autoantigens that could drive the expansion of the immune repertoire, but may also cause tissue injury or may modulate the immune response [200,201]. On the right genetic background, an autoantibody to a widely dispersed autoantigen, such as the nuclear antigens, that has the capacity to cross cell membranes and induce apoptosis could be the trigger for a greatly enhanced immune response to neoepitopes generated within the dying cells, but also release of the same cellular components to form immune complexes that could contribute to immune-mediated damage.

\section{Evidence for Pathogenicity of Autoantibodies to Intracellular Antigens}

In contrast to the previous examples of pathogenic autoantibodies to cell surface and extracellular antigens, there has been very little direct evidence that autoantibodies to intracellular antigens have any direct pathogenic effect. It has been assumed that pathogenesis is primarily T-cell mediated in the autoimmune diseases in which they occur, and the autoantibodies are merely markers of an autoimmune response. In this context, a recent study of uptake of autoantibodies to the cytoplasmic autoantigen Yo in Purkinje cells is of particular interest [193]. Anti-Yo is associated with paraneoplastic cerebellar degeneration associated with gynaecological and breast malignancies and is representative of a larger group of autoantibodies in paraneoplastic neurological syndromes targeting intracellular proteins [170]. The role of these autoantibodies has been unclear, as autoantibody levels do not correlate with disease severity, and prognosis is poor despite immunotherapies [202]. However, anti-Yo was shown to penetrate Purkinje cells, accumulate intracellularly, bind to the Yo antigen, and cause cell death, providing direct evidence that the autoantibodies may be directly pathogenic [193].

\subsection{Autoantibodies to Glutamic Acid Decarboxylase}

These autoantibodies represent an interesting example where two different populations of autoantibodies to the same intracellular antigen are associated with different diseases affecting different tissues. Glutamic acid decarboxylase is a pyridoxal-5'-phosphate (PLP) dependent enzyme that catalyses the production of the inhibitory neurotransmitter $\gamma$-amino butyric acid (GABA) from L-glutamate in the brain and in pancreatic islet $\beta$-cells where GABA has a paracrine function. It occurs as two isoforms, GAD65 and GAD67, GAD65 being most frequently autoantigenic. Autoantibodies to GAD65 occur in the serum of $70 \%-80 \%$ of subjects with type 1 diabetes $[203,204]$, and in certain neurological diseases, including Stiff Person Syndrome (SPS) characterized by progressive disabling muscle rigidity and spasms [205,206], but also in cerebellar ataxia, epilepsy, and various other disorders that may be related to altered GABA production in the central nervous system $[207,208]$. About $30 \%-50 \%$ of patients with GAD-related neurological diseases have diabetes, but SPS is rare in type 1 diabetes. Table 4 summarises the different autoantibody responses in type 1 diabetes and GAD-related neurological diseases that may be related to the structure and function of the two isoforms. 
Table 4. Comparison of autoantibodies to glutamic acid decarboxylase (GAD) in type 1 diabetes and SPS.

\begin{tabular}{|c|c|c|}
\hline & Type 1 Diabetes & SPS \\
\hline Autoantibody levels: serum & Low to moderate [209-211] & moderate to very high $[209,210,212,213]$ \\
\hline CSF & Not detected & oligoclonal [209,212,213] \\
\hline Frequency: anti-GAD65 & $70 \%-80 \%[214,215]$ & $70 \%-80 \%[217,218]$ \\
\hline Anti-GAD67 & $12 \%$ cross-reactive $[216]$ & $50 \%-60 \%[217,218]$ \\
\hline \multicolumn{3}{|l|}{ Immunofluorescence ${ }^{1}$} \\
\hline Pancreas & GAD65 [219] & GAD65 only [219] \\
\hline Brain & Minimal [219] & GAD65, 67 [219] \\
\hline Enzyme inhibition & $2 \%[217]$ & $60 \%[210,217]$ \\
\hline Western blotting: & $<10 \%[219-221]$ & GAD65 only [222] \\
\hline \multicolumn{3}{|l|}{ B cell epitopes: } \\
\hline GAD65 conformational & Catalytic region [223] & Catalytic region [222] \\
\hline GAD65 N-terminal linear & None ascertained [210,224] & Amino acids $4-22[210,224,225]$ \\
\hline GAD65 C-terminal linear & Rare & Amino acids $475-585$ [222] \\
\hline GAD67 conformational & GAD67 or GAD65 [216] & GAD67 specific $[210,224]$ \\
\hline Cross-inhibition (see text) & b96.11 > b78 [226] & b78 > b96.11 [210] \\
\hline \multirow{2}{*}{ Anti-GAD65 transfer to animals (see text) } & Diabetes: no & \multirow{2}{*}{ Not recorded } \\
\hline & Neurological: yes [227-231] & \\
\hline Other autoimmune diseases & Thyrogastric cluster [232] & Diabetes $30 \%-60 \%$ Thyrogastric cluster $[207,208]$ \\
\hline IvIg & ........ & Effective [234,235] \\
\hline Plasmapheresis & No effect [233] & ............ \\
\hline Rituximab & ......... & Varied [236-240] \\
\hline
\end{tabular}

${ }^{1}$ Defined by inhibition with recombinant GAD65 and/or GAD67.

The two isoforms of GAD are structurally very similar consisting of a highly conserved catalytic domain, with an N-terminal regulatory sequence of about 100 amino acids that differs substantially in sequence and represents the membrane-binding domain that co-localises GAD65 with the GABA-transporter on the membranes of synaptic vesicles [241,242]. There is no structural information available on this, but crystal structures have been derived for the N-terminally-truncated GAD65 and GAD67 catalytic domains, and these domains retain full enzymatic activity [243]. The two have different functions within the cell. GAD67 is continuously active, continuously produces GABA at a low level, and is predominantly cytoplasmic, whereas GAD65 occurs in the cell primarily as apoenzyme and provides an increased level of holo-enzyme in circumstances that demand a rapid surge of GABA synthesis and release, a process that involves translocation of GAD65 to the membrane of synaptic vesicles [242-244].

In type 1 diabetes, antibodies to GAD are almost entirely anti-GAD65: antibodies to GAD67 occur in only $10 \%-12 \%$ of patients, and represent a cross-reactive sub-population of anti-GAD65 [216]. The autoantibodies recognise highly conformational epitopes on GAD65 within the conserved catalytic domain, but not in the N-terminal membrane binding domain [223]. Despite reactivity with conformational epitopes in the catalytic domain, diabetes-associated autoantibodies to GAD are rarely enzyme inhibitory [217]. 
By contrast, in SPS and other anti-GAD-positive neurological diseases, very high levels of autoantibodies to both GAD65 and GAD67 occur, the autoantibodies can be detected by immunoblotting [245] and most sera are strongly enzyme inhibitory. Although sera from patients with SPS or other anti-GAD-positive neurological diseases, and sera from type 1 diabetics recognise epitopes across the catalytic domain of GAD65, an additional linear epitope in the N-terminal membrane-binding domain is present in SPS but not in type I diabetes [210,224,246].

In anti-GAD-positive neurological diseases, both anti-GAD65 and anti-GAD67 occur in the cerebrospinal fluid (CSF). Although the levels of antibodies are much lower than in serum they represent a proportionally greater fraction of the total $\mathrm{IgG}$, are often oligoclonal or monoclonal IgG antibodies, and may be produced intrathecally [209,211]. A comparison of anti-GAD65 and anti-GAD67 in paired samples of serum and CFS from 106 patients with anti-GAD-positive neurological conditions showed different responses in the two locations. Anti-GAD65 was present in all sera and anti-GAD67 was present in all CSF. However, there were 9 paired samples in which the CSF was positive for anti-GAD67 but the serum was negative [245].

Further evidence for differences in reactivity between type 1 diabetes and anti-GAD positive neurological diseases has come from epitope-mapping studies using recombinant Fab (rFab). Various human GAD-65-specific mAbs have been derived from patients with newly diagnosed type 1 diabetes or autoimmune polyendocrine syndrome 2 [247-250], and $\mathrm{rFab}$ has been prepared from several of them [226]. Although all of the mAb reacted with GAD65 only, and recognised multiple conformational epitopes in the catalytic domain, cross-inhibition studies with these rFab have revealed differences in the patterns of epitopes recognised in type 1 diabetes and SPS. In particular, antibodies reactive with an epitope defined by mAb b96.11 occurred in most patients with type 1 diabetes [226], whereas antibodies reactive with an epitope defined by mAb b78 were more closely associated with SPS, and mAb b78 inhibits the enzyme [210]. The b96.11 and b78 epitopes are predicted to be on opposing faces of the crystal structure [251]. The b78 epitope is in the C-terminal region that moves during catalysis, and co-locates with the N-terminal residues (from amino acid 84) in the crystal structure, close to the membrane binding domain. Moreover, in support of this, mAb b78, but not mAb b96.11 has been shown to disrupt the association of GAD with GABA-containing synaptic vesicles from rat brain in vitro [230]. Also, the human mAb b78 and to a lesser extent b96.11, have been shown to cause neurological changes when infused into the brains of animals [230]. Thus, there may be a major epitope region specifically associated with anti-GAD positive neurological diseases where autoantibodies could interfere with the GABAergic system in the central nervous system not only by direct inhibition of GABA synthesis, but also by interfering with membrane binding of GAD65 with the GABA transporter.

The question remains, whether these autoantibodies to intracellular antigens are pathogenic. Type I diabetes is generally considered to be primarily T-cell mediated. However, anti-GAD65 may be present in serum many years before the development of disease, and may predict progression to diabetes [252]. Although there is little evidence that autoantibodies to this important intracellular autoantigen are pathogenic per se, their role in the disease is yet to be elucidated.

In the case of SPS and other neurological diseases, there is more evidence that symptoms are antibody-mediated. In vitro, IgG from serum containing high levels of antibodies to GAD from patients with cerebellar ataxia have been shown to suppress GABA release in cerebellar slice preparations [253-257]. In vivo, infusions of IgG containing anti-GAD65 from patients with various neurological diseases have 
been shown by electrophysiology and neurochemistry to alter cerebellar activity, impair learning, and affect spinal cord activity in rats [231]. SPS has been successfully treated with intravenous Ig, and is the treatment of choice for intractable SPS [234,235], suggesting that antibodies may be important in pathogenesis. Although both GAD65 and GAD67 are intracellular antigens, the mAbs b78 and b96.11 have been shown to penetrate the AF5 rat CNS cell line [228], possibly being internalised by Fc receptors that are widely distributed in neural tissue including Purkinje cells [192,193]. As Purkinje cells are the major source of GABA in the brain, uptake of anti-GAD could disrupt function in these cells.

\subsection{Autoantibodies to the E2 Subunit of the Pyruvate Dehydrogenase Complex (PDC-E2)}

Primary biliary cirrhosis (PBC) is a rare chronic liver disease characterized by progressive obliterative cholangitis, with liver destruction and cirrhosis in which there is a strong diagnostic association with anti-mitochondrial autoantibodies to intracellular enzymes, the 2-oxoacid dehydrogenase complexes (OADC) that are essential enzymes in energy metabolism. The most frequent reactant is the E2 subunit of the pyruvate dehydrogenase complex, dihydrolipoamide acetyltransferase that has lipoic acid covalently attached as co-factor. Autoantibodies to E2 subunits of the related enzymes, 2-oxo-glutarate dehydrogenase complex (OGDC-E2) and the branched chain 2-oxo-acid dehydrogenase complex (BCOADC-E2) that share similar immunodominant epitope regions in the inner lipoyl domains of the three enzymes occur less frequently [258].

Anti-mitochondrial antibodies occur in sera many years before the development of symptoms, and are highly predictive of progression to primary biliary cirrhosis [259-262]. However, these enzymes are found throughout the body, yet the disease is limited to the biliary epithelial cells. An immunodominant epitope region has been identified in the inner lipoyl domain of PDC-E2, and initial tolerance breakdown has been attributed to xenobiotic modification of the lipoic acid cofactor causing cross-stimulation with a neo-epitope and epitope spreading to self-antigen in genetically susceptible individuals [263], but the autoantibodies associated with disease development are reactive with human PDC-E2, and not a neo-epitope [264]. Sera from patients with primary biliary cirrhosis contain very high titers of these autoantibodies, particularly anti-PDC-E2, and the autoantibodies are strongly enzyme inhibitory in vitro $[171,173,265,266]$. However, although primary biliary cirrhosis may recur after liver transplant, and all patients continue to produce high levels of autoantibodies, levels of serum autoantibodies have not been linked to recurrence of disease, and there is no direct evidence that the antibodies are pathogenic in vivo.

A possible clue to pathogenesis is the observation that PDC-E2 may be detected on the apical surface of biliary epithelium in patients with primary biliary cirrhosis, including some with donor livers [267,268]. Biliary epithelial cells have the capacity to export dimeric IgA to the bile by transcytosis, a process involving the polymeric immunoglobulin receptor (pIgR). Thus, the tissue specificity of the damage may be related to IgA anti-PDC-E2 transcytosed for secretion through the biliary epithelium that could carry PDC-E2 to the cell surface in the process. IgA antibodies have been described in in bile, saliva and urine in primary biliary cirrhosis [269-272] and the presence of IgA anti-PDC-E2 in serum and in saliva, has been linked to the histological progression of PBC [273].

Support for this hypothesis has come from studies of transcytosis of IgA into Madine-Darby canine kidney (MDCK) cells transfected with the human pIgR, in which IgA derived from patients with PBC 
penetrated the cells, colocalised with PDC-E2 within the cell [185], and induced caspase activation indicative of apoptosis [274]. Enhanced caspase activation was limited to patients with anti-PDC-E2 IgA expression, and required pIgR expression. Moreover, there was a strong correlation between the level of anti-PDC-E2 IgA and the degree of caspase activation [274]. Patients with PBC may complain of dry eyes and dry mouth, a feature of Sjögren's syndrome that is known to coexist with PBC [275]. As the pIgR is also found in the lacrimal and salivary glands, transcytosis of PDC-E2 could occur there also as abnormal apical staining of PDC-E2 has also been shown in salivary glands in patients with coexistent Sjögren's syndrome and primary biliary cirrhosis [276].

The importance of transcytosis of IgA anti-PDC-E2 in the development of liver damage and the sicca syndrome remains to be determined. IgA anti-PDC-E2 could play a direct role in pathogenesis by binding and inhibition of enzymes during transcytosis in the cell [272] or by depleting energy levels by transport of newly synthesized PDC out of the cell [270], or by apoptosis [263,277,278]. Although apoptotic bodies have been linked to increased antigen presentation and tolerance breakdown leading to autoimmunity, apoptosis has also been described as an outcome of cell penetration by antibodies, and interference with intracellular functions [177,181]. If this is the case, cell transport by the pIg receptor could provide both the initial stimulus for apoptosis of the biliary epithelial cells and massive amplification and ongoing antigenic stimulation when T-cell mediated processes become involved.

\section{Conclusions}

Autoimmune diseases are polygenic diseases, with more than 200 loci linked to their development, many of which are associated with the major histocompatibility complex and with particular pathways of inflammation or acquired or innate immunity that culminate in disease [279,280]. By the time the disease presents the situation is already complex as a result of many of these pathways. Both CD4 and CD8 T cells are involved, as well as various cells and cytokines associated with inflammation. One or several autoantibodies of different specificities may be present in the one disease and T-cell mediated pathogenic effects may also be operative. In this review we have been selective in our choice of autoantibodies to illustrate the pathogenic role they may have in autoimmune disease. However, we acknowledge they are only part of an extensive and expanding repertoire of autoantibodies of novel specificities, such as those associated with severe debilitating diseases of the nervous system [281]. Moreover, various autoantibodies have prognostic significance, such as antiphospholipid antibodies in SLE that may be associated with a more severe clinical outcome including more frequent renal disease, CNS involvement, thrombocytopenia and clotting events, or the autoantibodies to neuronal antigens associated with paraneoplastic syndromes [281].

Studies of mAbs have shown that not all autoantibodies contributing to a polyclonal response are equally pathogenic, although pathogenicity may be enhanced by combinations of mAbs. Differences in pathogenicity may be related to Fab-mediated diversity in epitope specificity, or to Fc-mediated effects based on class or subclass of antibody that include activation of complement and recruitment of effector cells common to pathways of both acquired and innate immunity. Moreover, pathogenic autoantibodies require access to the target autoantigen to exert a damaging effect. This is not only true for autoimmune diseases of the central nervous system that is protected from serum autoantibodies by the blood brain barrier, but also for autoantibodies to intracellular antigens such as dsDNA that require poly arginine 
peptide sequences in their antigen-binding domain to cross the cell membrane, and for antibodies to PDC-E2 that access biliary epithelial cells by the pIgR.

The initiation of the autoimmune response may occur long before symptoms appear as observed in population studies where autoantibodies have been detected in apparently healthy subjects many years before overt disease. Nonetheless, at this point a damaging autoantibody may be already exerting its pathogenic effect, and the outcome depends on a balance between damage and repair. This is exemplified by the damage to the extracellular matrix in primary cultures of bovine cartilage induced by mAb to CII where damage is much less in the presence of living chondrocytes responsible for its synthesis and repair than in their absence [61]. Over time, those damaging effects may be small but significant, given that there will be a balance between antibody-induced destruction and on-going cell-mediated repair, and this balance will depend on the level and pathogenicity of the antibody and the vitality of the cell.

It is plausible that many autoantibodies initiate the damage that leads to autoimmune diseases, and this damage is enhanced by the same $\mathrm{T}$ cell activation and inflammation that amplify normal responses to foreign antigens. In that case, the response amplified by antibodies, cytotoxic $\mathrm{T}$ cells and inflammation results in the elimination of the foreign antigen and the process subsides. In the case of an autoantigen, the antigen is self, and amplification of effector responses leads to tissue damage, release of new autoantigens, and an amplified and on-going response. This proceeds unless the autoantigen can be completely destroyed, as occurs in autoimmune thyroiditis. This scenario would be consistent with the fruitless search for infectious origins of autoimmune diseases.

Overall, autoimmunity is one of the most common causes of disease, and in the absence of therapeutic intervention, autoimmune diseases become chronic with a high level of morbidity. Treatment is aimed at reducing symptoms, preventing progressive damage and dampening inflammation, and if the disease terminates in loss of autoantigen, treatment is by replacement therapy, such as thyroid hormone replacement in autoimmune thyroiditis, and insulin replacement in type 1 diabetes. New generation drugs being developed for treatment are expensive, not without side-effects, and often employed as drugs of last resort rather than as therapies rationally selected by an understanding of the disease process. Knowledge of the ways in which autoantibodies cause damage, and the biochemical and immunological pathways that are involved may identify the particular clones of B-cells responsible for the most damaging or distressing symptoms, and selection of appropriate treatments to suppress or eradicate them.

\section{Acknowledgments}

The authors would like to thank Elaine Pearson for help with the manuscript, and the Department of Biochemistry and Molecular Biology for providing the research facilities for this work.

\section{Author Contributions}

Merrill Rowley wrote the manuscript and prepared the Tables. Senga Whittingham provided detailed clinical input and reviewed and revised the manuscript.

\section{Conflicts of Interest}

The authors declare no conflict of interest. 


\section{References}

1. Donath, J.; Landsteiner, J. Ueber paroxysmale Hämoglobinurie. Münch. Med. Wschr. 1904, 51, 1590-1593.

2. Witebsky, E.; Rose, N.R.; Terplan, K.; Paine, J.R.; Egan, R.W. Chronic thyroiditis and autoimmunization. J. Am. Med. Assoc. 1957, 164, 1439-1447.

3. Doniach, D.; Roitt, I.M. Auto-immunity in Hashimoto's disease and its implications. J. Clin. Endocrinol. Metab. 1957, 17, 1293-1304.

4. Baumann, R.; Rubin, H. Autoimmune hemolytic anemia during pregnancy with hemolytic disease in the newborn. Blood 1973, 41, 293-297.

5. Shibata, T.; Berney, T.; Reininger, L.; Chicheportiche, Y.; Ozaki, S.; Shirai, T.; Izui, S. Monoclonal anti-erythrocyte autoantibodies derived from NZB mice cause autoimmune hemolytic anemia by two distinct pathogenic mechanisms. Int. Immunol. 1990, 2, 1133-1141.

6. Robson, H.N.; Walker, C.H.M. Congenital and neonatal thrombocytopenic purpura. Arch. Dis. Child. 1951, 26, 175-183.

7. Karpatkin, S. Autoimmune thrombocytopenic purpura. Blood 1980, 56, 329-343.

8. Godeau, B.; Porcher, R.; Fain, O.; Lefrère, F.; Fenaux, P.; Cheze, S.; Vekhoff, A.; Chauveheid, M.-P.; Stirnemann, J.; Galicier, L.; et al. Rituximab efficacy and safety in adult splenectomy candidates with chronic immune thrombocytopenic purpura: Results of a prospective multicenter phase 2 study. Blood 2008, 112, 999-1004.

9. Green, D.; Maize, J.C. Maternal pemphigus vulgaris with in vivo bound antibodies in the stillborn fetus. J. Am. Acad. Dermatol. 1982, 7, 388-392.

10. Hup, J.M.; Bruinsma, R.A.; Boersma, E.R.; de Jong, M.C. Neonatal pemphigus vulgaris: Transplacental transmission of antibodies. Pediatr. Dermatol. 1986, 3, 468-472.

11. Moncada, B.; Kettelsen, S.; Hernández-Moctezuma, J.L.; Ramirez, F. Neonatal pemphigus vulgaris: Role of passively transferred pemphigus antibodies. Br. J. Dermatol. 1982, 106, 465-467.

12. Storer, J.S.; Galen, W.K.; Nesbitt, L.T.; DeLeo, V.A. Neonatal pemphigus vulgaris. J. Am. Acad. Dermatol. 1982, 6, 929-932.

13. Campo-Voegeli, A.; Muñiz, F.; Mascaró, J.M.; García, F.; Casals, M.; Arimany, J.L.; Amagai, M.; Camps, A. Neonatal pemphigus vulgaris with extensive mucocutaneous lesions from a mother with oral pemphigus vulgaris. Br. J. Dermatol. 2002, 147, 801-805.

14. Anhalt, G.J.; Labib, R.S.; Voorhees, J.J.; Beals, T.F.; Diaz, L.A. Induction of pemphigus in neonatal mice by passive transfer of IgG from patients with the disease. N. Engl. J. Med. 1982, 306, 1189-1196.

15. Roscoe, J.T.; Diaz, L.; Sampaio, S.A.; Castro, R.M.; Labib, R.S.; Takahashi, Y.; Patel, H.; Anhalt, G.J. Brazilian pemphigus foliaceus autoantibodies are pathogenic to BALB/c mice by passive transfer. J. Invest. Dermatol. 1985, 85, 538-541.

16. Amagai, M. Pemphigus vulgaris and its active disease mouse model. Curr. Dir. Autoimmun. 2008, 10, 167-181.

17. Kawasaki, H.; Tsunoda, K.; Hata, T.; Ishii, K.; Yamada, T.; Amagai, M. Synergistic pathogenic effects of combined mouse monoclonal anti-desmoglein $3 \mathrm{IgG}$ antibodies on pemphigus vulgaris blister formation. J. Invest. Dermatol. 2006, 126, 2621-2630. 
18. Ishii, K.; Harada, R.; Matsuo, I.; Shirakata, Y.; Hashimoto, K.; Amagai, M. In vitro keratinocyte dissociation assay for evaluation of the pathogenicity of anti-desmoglein $3 \mathrm{IgG}$ autoantibodies in pemphigus vulgaris. J. Invest. Dermatol. 2005, 124, 939-946.

19. Ahmed, A.R.; Spigelman, Z.; Cavacini, L.A.; Posner, M.R. Treatment of pemphigus vulgaris with rituximab and intravenous immune globulin. N. Engl. J. Med. 2006, 355, 1772-1779.

20. Gürcan, H.M.; Jeph, S.; Ahmed, A.R. Intravenous immunoglobulin therapy in autoimmune mucocutaneous blistering diseases: A review of the evidence for its efficacy and safety. Am. J. Clin. Dermatol. 2010, 11, 315-326.

21. Chorzelski, T.P.; Jablonska, S.; Beutner, E.H.; Maciejowska, E.; Jarzabek-Chorzelska, M. Herpes gestations with identical lesions in the newborn. Passive transfer of the disease? Arch. Dermatol. 1976, 112, 1129-1131.

22. Katz, A.; Minto, J.O.; Toole, J.W.; Medwidsky, W. Immunopathologic study of herpes gestationis in mother and infant. Arch. Dermatol. 1977, 113, 1069-1072.

23. Sams, W.M.; Gleich, G.J. Failure to transfer bullous pemphigoid with serum from patients. Proc. Soc. Exp. Biol. Med. 1971, 136, 1027-1031.

24. Chiriac, M.T.; Licarete, E.; Sas, A.G.; Rados, A.M.; Lupan, I.; Chiriac, A.M.; Speth, H.; Pop-Vancia, V.; Domsa, I.; Sesarman, A.; et al. Passive transfer of collagen XVII-specific antibodies induces sustained blistering disease in adult mice. Orphanet J. Rare Dis. 2013, 8, 17.

25. Heimbach, L.; Li, Z.; Berkowitz, P.; Zhao, M.; Li, N.; Rubenstein, D.S.; Diaz, L.A.; Liu, Z. The C5a receptor on mast cells is critical for the autoimmune skin-blistering disease bullous pemphigoid. J. Biol. Chem. 2011, 286, 15003-15009.

26. Lin, L.; Betsuyaku, T.; Heimbach, L.; Li, N.; Rubenstein, D.; Shapiro, S.D.; An, L.; Giudice, G.J.; Diaz, L.A.; Senior, R.M.; et al. Neutrophil elastase cleaves the murine hemidesmosomal protein BP180/type XVII collagen and generates degradation products that modulate experimental bullous pemphigoid. Matrix Biol. 2012, 31, 38-44.

27. Liu, Z.; Diaz, L.A.; Troy, J.L.; Taylor, A.F.; Emery, D.J.; Fairley, J.A.; Giudice, G.J. A passive transfer model of the organ-specific autoimmune disease, bullous pemphigoid, using antibodies generated against the hemidesmosomal antigen, BP180. J. Clin. Invest. 1993, 92, 2480-2488.

28. Sitaru, C.; Schmidt, E.; Petermann, S.; Munteanu, L.S.; Bröcker, E.-B.; Zillikens, D. Autoantibodies to bullous pemphigoid antigen 180 induce dermal-epidermal separation in cryosections of human skin. J. Invest. Dermatol. 2002, 118, 664-671.

29. Egan, C.A.; Meadows, K.P.; Zone, J.J. Plasmapheresis as a steroid saving procedure in bullous pemphigoid. Int. J. Dermatol. 2000, 39, 230-235.

30. Woodley, D.T.; Ram, R.; Doostan, A.; Bandyopadhyay, P.; Huang, Y.; Remington, J.; Hou, Y.; Keene, D.R.; Liu, Z.; Chen, M. Induction of epidermolysis bullosa acquisita in mice by passive transfer of autoantibodies from patients. J. Invest. Dermatol. 2006, 126, 1323-1330.

31. Sitaru, C.; Mihai, S.; Otto, C.; Chiriac, M.T.; Hausser, I.; Dotterweich, B.; Saito, H.; Rose, C.; Ishiko, A.; Zillikens, D. Induction of dermal-epidermal separation in mice by passive transfer of antibodies specific to type VII collagen. J. Clin. Invest. 2005, 115, 870-878.

32. Sitaru, C.; Kromminga, A.; Hashimoto, T.; Bröcker, E.B.; Zillikens, D. Autoantibodies to type VII collagen mediate Fcgamma-dependent neutrophil activation and induce dermal-epidermal separation in cryosections of human skin. Am. J. Pathol. 2002, 161, 301-311. 
33. Furue, M.; Iwata, M.; Yoon, H.I.; Kubota, Y.; Ohto, H.; Kawashima, M.; Tsuchida, T.; Oohara, K.; Tamaki, K.; Kukita, A. Epidermolysis bullosa acquisita: Clinical response to plasma exchange therapy and circulating anti-basement membrane zone antibody titer. J. Am. Acad. Dermatol. 1986, 14, 873-878.

34. Volpe, R. Thyrotropin Receptor Autoantibodies. In Autoantibodies; Peter, J.B., Shoenfeld, Y., Eds.; Elsevier Science B.V: Philadelphia, PA, USA, 1996; pp. 822-829.

35. Weetman, A.P.; McGregor, A.M. Autoimmune thyroid disease: Further developments in our understanding. Endocr. Rev. 1994, 15, 788-830.

36. Matsuura, N.; Yamada, Y.; Nohara, Y.; Konishi, J.; Kasagi, K.; Endo, K.; Kojima, H.; Wataya, K. Familial neonatal transient hypothyroidism due to maternal TSH-binding inhibitor immunoglobulins. N. Engl. J. Med. 1980, 303, 738-741.

37. Adams, D.D. Long-acting thyroid stimulator: How receptor autoimmunity was discovered. Autoimmunity 1988, 1, 3-9.

38. Tanaka, N.; Glass, V.B. Effect of prolonged administration of parietal cell antibodies from patients with atrophic gastritis and pernicious anemia on the parietal cell mass and hydrochloric acid output in rats. Gastroenterology 1970, 58, 482-494.

39. Burman, P.; Mårdh, S.; Norberg, L.; Karlsson, F.A. Parietal cell antibodies in pernicious anemia inhibit $\mathrm{H}^{+}, \mathrm{K}^{+}$-adenosine triphosphatase, the proton pump of the stomach. Gastroenterology 1989, 96, 1434-1438.

40. Robinson, C.P.; Brayer, J.; Yamachika, S.; Esch, T.R.; Peck, A.B.; Stewart, C.A.; Peen, E.; Jonsson, R.; Humphreys-Beher, M.G. Transfer of human serum IgG to nonobese diabetic Igmu null mice reveals a role for autoantibodies in the loss of secretory function of exocrine tissues in Sjögren's syndrome. Proc. Natl. Acad. Sci. USA 1998, 95, 7538-7543.

41. Wang, F.; Jackson, M.W.; Maughan, V.; Cavill, D.; Smith, A.J.; Waterman, S.A.; Gordon, T.P. Passive transfer of Sjogren's syndrome IgG produces the pathophysiology of overactive bladder. Arthritis Rheum. 2004, 50, 3637-3645.

42. Cavill, D.; Waterman, S.A.; Gordon, T.P. Antiidiotypic antibodies neutralize autoantibodies that inhibit cholinergic neurotransmission. Arthritis Rheum. 2003, 48, 3597-3602.

43. Smith, A.J.; Jackson, M.W.; Wang, F.; Cavill, D.; Rischmueller, M.; Gordon, T.P. Neutralization of muscarinic receptor autoantibodies by intravenous immunoglobulin in Sjögren syndrome. Hum. Immunol. 2005, 66, 411-416.

44. Morel, E.; Eymard, B.; Vernet-der Garabedian, B.; Pannier, C.; Dulac, O.; Bach, J.F. Neonatal myasthenia gravis: A new clinical and immunologic appraisal on 30 cases. Neurology 1988, 38, $138-142$.

45. Vernet-der Garabedian, B.; Lacokova, M.; Eymard, B.; Morel, E.; Faltin, M.; Zajac, J.; Sadovsky, O.; Dommergues, M.; Tripon, P.; Bach, J.F. Association of neonatal myasthenia gravis with antibodies against the fetal acetylcholine receptor. J. Clin. Invest. 1994, 94, 555-559.

46. Toyka, K.V.; Drachman, D.B.; Griffin, D.E.; Pestronk, A.; Winkelstein, J.A.; Fishbeck, K.H.; Kao, I. Myasthenia gravis. Study of humoral immune mechanisms by passive transfer to mice. N. Engl. J. Med. 1977, 296, 125-131. 
47. Kordas, G.; Lagoumintzis, G.; Sideris, S.; Poulas, K.; Tzartos, S.J. Direct proof of the in vivo pathogenic role of the AChR autoantibodies from myasthenia gravis patients. PLoS ONE 2014, 9, e108327.

48. Tzartos, S.; Hochschwender, S.; Vasquez, P.; Lindstrom, J. Passive transfer of experimental autoimmune myasthenia gravis by monoclonal antibodies to the main immunogenic region of the acetylcholine receptor. J. Neuroimmunol. 1987, 15, 185-194.

49. Benveniste, O; Hilton-Jones, D. The role of rituximab in the treatment of myasthenia gravis. Eur. Neurol. Rev. 2010, 5, 95.

50. Thorlacius, S.; Lefvert, A.K.; Aarli, J.A.; Gilhus, N.E.; Halvorsen, K.; Hofstad, H.; Matre, R.; Tönder, O. Plasma exchange in myasthenia gravis: Effect on anti-AChR antibodies and other autoantibodies. Acta Neurol. Scand. 1986, 74, 486-490.

51. Gwathmey, K.; Balogun, R.A.; Burns, T. Neurologic indications for therapeutic plasma exchange: 2013 update. J. Clin. Apheresis 2014, 29, 211-219.

52. Reuner, U.; Kamin, G.; Ramantani, G.; Reichmann, H.; Dinger, J. Transient neonatal Lambert-Eaton syndrome. J. Neurol. 2008, 255, 1827-1828.

53. Fukunaga, H.; Engel, A.G.; Lang, B.; Newsom-Davis, J.; Vincent, A. Passive transfer of Lambert-Eaton myasthenic syndrome with $\mathrm{IgG}$ from man to mouse depletes the presynaptic membrane active zones. Proc. Natl. Acad. Sci. USA 1983, 80, 7636-7640.

54. Lang, B.; Newsom-Davis, J.; Peers, C.; Prior, C.; Wray, D.W. The effect of myasthenic syndrome antibody on presynaptic calcium channels in the mouse. J. Physiol. (Lond.) 1987, 390, 257-270.

55. Kim, Y.I. Passive transfer of the Lambert-Eaton myasthenic syndrome: Neuromuscular transmission in mice injected with plasma. Muscle Nerve 1985, 8, 162-172.

56. Wooley, P.H.; Luthra, H.S.; Singh, S.K.; Huse, A.R.; Stuart, J.M.; David, C.S. Passive transfer of arthritis to mice by injection of human anti-type II collagen antibody. Mayo Clin. Proc. 1984, 59, 737-743.

57. Nandakumar, K.S.; Svensson, L.; Holmdahl, R. Collagen type II-specific monoclonal antibody-induced arthritis in mice: Description of the disease and the influence of age, sex, and genes. Am. J. Pathol. 2003, 163, 1827-1837.

58. Amirahmadi, S.F.; Whittingham, S.; Crombie, D.E.; Nandakumar, K.S.; Holmdahl, R.; Mackay, I.R.; van Damme, M.-P.; Rowley, M.J. Arthritogenic anti-type II collagen antibodies are pathogenic for cartilage-derived chondrocytes independent of inflammatory cells. Arthritis Rheum. 2005, 52, 1897-1906.

59. Amirahmadi, S.F.; Pho, M.H.; Gray, R.E.; Crombie, D.E.; Whittingham, S.F.; Zuasti, B.B.; van Damme, M.-P.; Rowley, M.J. An arthritogenic monoclonal antibody to type II collagen, CII-C1, impairs cartilage formation by cultured chondrocytes. Immunol. Cell Biol. 2004, 82, 427-434.

60. Crombie, D.E.; Turer, M.; Zuasti, B.B.; Wood, B.; McNaughton, D.; Nandakumar, K.S.; Holmdahl, R.; van Damme, M.-P.; Rowley, M.J. Destructive effects of murine arthritogenic antibodies to type II collagen on cartilage explants in vitro. Arthritis Res. Ther. 2005, 7, R927-R937.

61. Croxford, A.M.; Crombie, D.; McNaughton, D.; Holmdahl, R.; Nandakumar, K.S.; Rowley, M.J. Specific antibody protection of the extracellular cartilage matrix against collagen antibody-induced damage. Arthritis Rheum. 2010, 62, 3374-3384. 
62. Nandakumar, K.S.; Bajtner, E.; Hill, L.; Böhm, B.; Rowley, M.J.; Burkhardt, H.; Holmdahl, R. Arthritogenic antibodies specific for a major type II collagen triple-helical epitope bind and destabilize cartilage independent of inflammation. Arthritis Rheum. 2008, 58, 184-196.

63. Edwards, J.C.W.; Szczepanski, L.; Szechinski, J.; Filipowicz-Sosnowska, A.; Emery, P.; Close, D.R.; Stevens, R.M.; Shaw, T. Efficacy of B-cell-targeted therapy with rituximab in patients with rheumatoid arthritis. N. Engl. J. Med. 2004, 350, 2572-2581.

64. Dwosh, I.L.; Giles, A.R.; Ford, P.M.; Pater, J.L.; Anastassiades, T.P. Plasmapheresis therapy in rheumatoid arthritis. A controlled, double-blind, crossover trial. N. Engl. J. Med. 1983, 308, 1124-1129.

65. Adams, D.D.; Fastier, F.N.; Howie, J.B.; Kennedy, T.H.; Kilpatrick, J.A.; Stewart, R.D. Stimulation of the human thyroid by infusions of plasma containing LATS protector. J. Clin. Endocrinol. Metab. 1974, 39, 826-832.

66. Appel, S.H.; Engelhardt, J.I.; Garcia, J.; Stefani, E. Immunoglobulins from animal models of motor neuron disease and from human amyotrophic lateral sclerosis patients passively transfer physiological abnormalities to the neuromuscular junction. Proc. Natl. Acad. Sci. USA 1991, 88, 647-651.

67. Terato, K.; Hasty, K.A.; Reife, R.A.; Cremer, M.A.; Kang, A.H.; Stuart, J.M. Induction of arthritis with monoclonal antibodies to collagen. J. Immunol.1992, 148, 2103-2108.

68. Anhalt, G.J.; Till, G.O.; Diaz, L.A.; Labib, R.S.; Patel, H.P.; Eaglstein, N.F. Defining the role of complement in experimental pemphigus vulgaris in mice. J. Immunol. 1986, 137, 2835-2840.

69. España, A.; Diaz, L.A.; Mascaró, J.M.; Giudice, G.J.; Fairley, J.A.; Till, G.O.; Liu, Z. Mechanisms of acantholysis in pemphigus foliaceus. Clin. Immunol. Immunopathol. 1997, 85, 83-89.

70. Payne, A.S.; Ishii, K.; Kacir, S.; Lin, C.; Li, H.; Hanakawa, Y.; Tsunoda, K.; Amagai, M.; Stanley, J.R.; Siegel, D.L. Genetic and functional characterization of human pemphigus vulgaris monoclonal autoantibodies isolated by phage display. J. Clin. Invest. 2005, 115, 888-899.

71. Rock, B.; Labib, R.S.; Diaz, L.A. Monovalent Fab' immunoglobulin fragments from endemic pemphigus foliaceus autoantibodies reproduce the human disease in neonatal Balb/c mice. J. Clin. Invest. 1990, 85, 296-299.

72. Graus, Y.F.; de Baets, M.H.; van Breda Vriesman, P.J.; Burton, D.R. Anti-acetylcholine receptor Fab fragments isolated from thymus-derived phage display libraries from myasthenia gravis patients reflect predominant specificities in serum and block the action of pathogenic serum antibodies. Immunol. Lett. 1997, 57, 59-62.

73. Graus, Y.F.; de Baets, M.H.; Parren, P.W.; Berrih-Aknin, S.; Wokke, J.; van Breda Vriesman, P.J.; Burton, D.R. Human anti-nicotinic acetylcholine receptor recombinant Fab fragments isolated from thymus-derived phage display libraries from myasthenia gravis patients reflect predominant specificities in serum and block the action of pathogenic serum antibodies. J. Immunol.1997, 158, 1919-1929.

74. Nagel, A.; Engel, A.G.; Lang, B.; Newsom-Davis, J.; Fukuoka, T. Lambert-Eaton myasthenic syndrome IgG depletes presynaptic membrane active zone particles by antigenic modulation. Ann. Neurol. 1988, 24, 552-558. 
75. Peers, C.; Johnston, I.; Lang, B.; Wray, D. Cross-linking of presynaptic calcium channels: A mechanism of action for Lambert-Eaton myasthenic syndrome antibodies at the mouse neuromuscular junction. Neurosci. Lett. 1993, 153, 45-48.

76. Burkovitz, A.; Sela-Culang, I.; Ofran, Y. Large-scale analysis of somatic hypermutations in antibodies reveals which structural regions, positions and amino acids are modified to improve affinity. FEBS J. 2014, 281, 306-319.

77. Clark, L.A.; Ganesan, S.; Papp, S.; van Vlijmen, H.W.T. Trends in antibody sequence changes during the somatic hypermutation process. J. Immunol. 2006, 177, 333-340.

78. Hampe, C.S. Protective role of anti-idiotypic antibodies in autoimmunity-Lessons for type 1 diabetes. Autoimmunity 2012, 45, 320-331.

79. Hashira, S.; Okitsu-Negishi, S.; Yoshino, K. Placental transfer of IgG subclasses in a Japanese population. Pediatr. Int. 2000, 42, 337-342.

80. Bindon, C.I.; Hale, G.; Brüggemann, M.; Waldmann, H. Human monoclonal IgG isotypes differ in complement activating function at the level of $\mathrm{C} 4$ as well as C1q. J. Exp. Med. 1988, 168, 127-142.

81. Bruhns, P.; Iannascoli, B.; England, P.; Mancardi, D.A.; Fernandez, N.; Jorieux, S.; Daëron, M. Specificity and affinity of human Fcgamma receptors and their polymorphic variants for human IgG subclasses. Blood 2009, 113, 3716-3725.

82. Guilliams, M.; Bruhns, P.; Saeys, Y.; Hammad, H.; Lambrecht, B.N. The function of Fcy receptors in dendritic cells and macrophages. Nat. Rev. Immunol. 2014, 14, 94-108.

83. Duncan, A.R.; Winter, G. The binding site for C1q on IgG. Nature 1988, 332, 738-740.

84. Karsten, C.M.; Köhl, J. The immunoglobulin, IgG Fc receptor and complement triangle in autoimmune diseases. Immunobiology 2012, 217, 1067-1079.

85. Nimmerjahn, F.; Ravetch, J.V. Fcy receptors as regulators of immune responses. Nat. Rev. Immunol. 2008, 8, 34-47.

86. Azeredo da Silveira, S.; Kikuchi, S.; Fossati-Jimack, L.; Moll, T.; Saito, T.; Verbeek, J.S.; Botto, M.; Walport, M.J.; Carroll, M.; Izui, S. Complement activation selectively potentiates the pathogenicity of the $\operatorname{IgG} 2 \mathrm{~b}$ and $\mathrm{IgG} 3$ isotypes of a high affinity anti-erythrocyte autoantibody. J. Exp. Med. 2002, 195, 665-672.

87. Baudino, L.; Azeredo da Silveira, S.; Nakata, M.; Izui, S. Molecular and cellular basis for pathogenicity of autoantibodies: Lessons from murine monoclonal autoantibodies. Springer Semin. Immunopathol. 2006, 28, 175-184.

88. Fossati-Jimack, L.; Reininger, L.; Chicheportiche, Y.; Clynes, R.; Ravetch, J.V.; Honjo, T.; Izui, S. High pathogenic potential of low-affinity autoantibodies in experimental autoimmune hemolytic anemia. J. Exp. Med. 1999, 190, 1689-1696.

89. Fossati-Jimack, L.; Ioan-Facsinay, A.; Reininger, L.; Chicheportiche, Y.; Watanabe, N.; Saito, T.; Hofhuis, F.M.; Gessner, J.E.; Schiller, C.; Schmidt, R.E.; et al. Markedly different pathogenicity of four immunoglobulin $\mathrm{G}$ isotype-switch variants of an antierythrocyte autoantibody is based on their capacity to interact in vivo with the low-affinity Fcgamma receptor III. J. Exp. Med. 2000, $191,1293-1302$. 
90. Mohamed, H.A.; Mosier, D.R.; Zou, L.L.; Siklós, L.; Alexianu, M.E.; Engelhardt, J.I.; Beers, D.R.; Le, W.; Appel, S.H. Immunoglobulin Fc gamma receptor promotes immunoglobulin uptake, immunoglobulin-mediated calcium increase, and neurotransmitter release in motor neurons. J. Neurosci. Res. 2002, 69, 110-116.

91. Okun, E.; Mattson, M.P.; Arumugam, T.V. Involvement of Fc Receptors in Disorders of the Central Nervous System. NeuroMol. Med. 2010, 12, 164-178.

92. Kaetzel, C.S. The polymeric immunoglobulin receptor: Bridging innate and adaptive immune responses at mucosal surfaces. Immunol. Rev. 2005, 206, 83-99.

93. Shah, U.; Dickinson, B.L.; Blumberg, R.S.; Simister, N.E.; Lencer, W.I.; Walker, W.A. Distribution of the IgG Fc receptor, FcRn, in the human fetal intestine. Pediatr. Res. 2003, 53, 295-301.

94. Simister, N.E. Placental transport of immunoglobulin G. Vaccine 2003, 21, 3365-3369.

95. Kuo, T.T.; Baker, K.; Yoshida, M.; Qiao, S.-W.; Aveson, V.G.; Lencer, W.I.; Blumberg, R.S. Neonatal Fc receptor: From immunity to therapeutics. J. Clin. Immunol. 2010, 30, 777-789.

96. Bonanni, A.; Vaglio, A.; Bruschi, M.; Sinico, R.A.; Cavagna, L.; Moroni, G.; Franceschini, F.; Allegri, L.; Pratesi, F.; Migliorini, P.; et al. Multi-antibody composition in lupus nephritis: Isotype and antigen specificity make the difference. Autoimmun. Rev. 2015, 14, doi: 10.1016/j.autrev.2015.04.004.

97. Bruschi, M.; Galetti, M.; Sinico, R.A.; Moroni, G.; Bonanni, A.; Radice, A.; Tincani, A.; Pratesi, F.; Migliorini, P.; Murtas, C.; et al. Glomerular autoimmune multicomponents of human lupus nephritis in vivo (2): Planted antigens. J. Am. Soc. Nephrol. 2015, 26, doi: 10.1681/ASN.2014050493.

98. Mannik, M.; Merrill, C.E.; Stamps, L.D.; Wener, M.H. Multiple autoantibodies form the glomerular immune deposits in patients with systemic lupus erythematosus. J. Rheumatol. 2003, 30, 1495-1504.

99. Dinarello, C.A. Anti-inflammatory agents: Present and future. Cell 2010, 140, 935-950.

100. Feldmann, M. Development of anti-TNF therapy for rheumatoid arthritis. Nat. Rev. Immunol. 2002, 2, 364-371.

101. Amagai, M.; Nishikawa, T.; Nousari, H.C.; Anhalt, G.J.; Hashimoto, T. Antibodies against desmoglein 3 (pemphigus vulgaris antigen) are present in sera from patients with paraneoplastic pemphigus and cause acantholysis in vivo in neonatal mice. J. Clin. Invest. 1998, 102, 775-782.

102. Shimizu, A.; Ishiko, A.; Ota, T.; Tsunoda, K.; Amagai, M.; Nishikawa, T. IgG binds to desmoglein 3 in desmosomes and causes a desmosomal split without keratin retraction in a pemphigus mouse model. J. Invest. Dermatol. 2004, 122, 1145-1153.

103. Seiffert-Sinha, K.; Yang, R.; Fung, C.K.; Lai, K.W.; Patterson, K.C.; Payne, A.S.; Xi, N.; Sinha, A.A. Nanorobotic investigation identifies novel visual, structural and functional correlates of autoimmune pathology in a blistering skin disease model. PLOS ONE 2014, 9, e106895.

104. Li, N.; Aoki, V.; Hans-Filho, G.; Rivitti, E.A.; Diaz, L.A. The role of intramolecular epitope spreading in the pathogenesis of endemic pemphigus foliaceus (fogo selvagem). J. Exp. Med. 2003, 197, 1501-1510.

105. Sekiguchi, M.; Futei, Y.; Fujii, Y.; Iwasaki, T.; Nishikawa, T.; Amagai, M. Dominant autoimmune epitopes recognized by pemphigus antibodies map to the $\mathrm{N}$-terminal adhesive region of desmogleins. J. Immunol. 2001, 167, 5439-5448. 
106. Bhol, K.C.; Ahmed, A.R. Production of non-pathogenic human monoclonal antibodies to desmoglein 3 from pemphigus vulgaris patient. Autoimmunity 2002, 35, 87-91.

107. Yeh, S.-W.; Cavacini, L.A.; Bhol, K.C.; Lin, M.-S.; Kumar, M.; Duval, M.; Posner, M.R.; Ahmed, A.R. Pathogenic human monoclonal antibody against desmoglein 3. Clin. Immunol. 2006, 120, 68-75.

108. Kowalczyk, A.P.; Anderson, J.E.; Borgwardt, J.E.; Hashimoto, T.; Stanley, J.R.; Green, K.J. Pemphigus sera recognize conformationally sensitive epitopes in the amino-terminal region of desmoglein-1. J. Invest. Dermatol. 1995, 105, 147-152.

109. Giudice, G.J.; Emery, D.J.; Diaz, L.A. Cloning and primary structural analysis of the bullous pemphigoid autoantigen BP180. J. Invest. Dermatol. 1992, 99, 243-250.

110. Giudice, G.J.; Emery, D.J.; Zelickson, B.D.; Anhalt, G.J.; Liu, Z.; Diaz, L.A. Bullous pemphigoid and herpes gestationis autoantibodies recognize a common non-collagenous site on the BP180 ectodomain. J. Immunol. 1993, 151, 5742-5750.

111. Lin, M S.; Gharia, M.; Fu, C.L.; Olague-Marchan, M.; Hacker, M.; Harman, K.E.; Bhogal, B.S.; Black, M.M.; Diaz, L.A.; Giudice, G.J. Molecular mapping of the major epitopes of BP180 recognized by herpes gestationis autoantibodies. Clin. Immunol. 1999, 92, 285-292.

112. Zillikens, D.; Rose, P.A.; Balding, S.D.; Liu, Z.; Olague-Marchan, M.; Diaz, L.A.; Giudice, G.J. Tight clustering of extracellular BP180 epitopes recognized by bullous pemphigoid autoantibodies. J. Invest. Dermatol. 1997, 109, 573-579.

113. Gupta, R.; Woodley, D.T.; Chen, M. Epidermolysis bullosa acquisita. Clin. Dermatol. 2012, 30, 60-69.

114. Borradori, L.; Caldwell, J.B.; Briggaman, R.A.; Burr, C.E.; Gammon, W.R.; James, W.D.; Yancey, K.B. Passive transfer of autoantibodies from a patient with mutilating epidermolysis bullosa acquisita induces specific alterations in the skin of neonatal mice. Arch. Dermatol. 1995, 131, 590-595.

115. Shigemoto, T.; Nashiro, K.; Tsuchida, T.; Seki, Y.; Tamaki, K. Administration of IgG fraction of epidermolysis bullosa acquisita (EBA) serum into mice. J. Dermatol. 1988, 15, 123-127.

116. Csorba, K.; Chiriac, M.T.; Florea, F.; Ghinia, M.G.; Licarete, E.; Rados, A.; Sas, A.; Vuta, V.; Sitaru, C. Blister-inducing antibodies target multiple epitopes on collagen VII in mice. J. Cell. Mol. Med. 2014, 18, 1727-1739.

117. Sitaru, C.; Mihai, S.; Zillikens, D. The relevance of the IgG subclass of autoantibodies for blister induction in autoimmune bullous skin diseases. Arch. Dermatol. Res. 2007, 299, 1-8.

118. Jones, C.C.; Hamilton, R.G.; Jordon, R.E. Subclass distribution of human IgG autoantibodies in pemphigus. J. Clin. Immunol. 1988, 8, 43-49.

119. Rock, B.; Martins, C.R.; Theofilopoulos, A.N.; Balderas, R.S.; Anhalt, G.J.; Labib, R.S.; Futamura, S.; Rivitti, E.A.; Diaz, L.A. The pathogenic effect of IgG4 autoantibodies in endemic pemphigus foliaceus (fogo selvagem). N. Engl. J. Med. 1989, 320, 1463-1469.

120. Hofmann, S.; Thoma-Uszynski, S.; Hunziker, T.; Bernard, P.; Koebnick, C.; Stauber, A.; Schuler, G.; Borradori, L.; Hertl, M. Severity and phenotype of bullous pemphigoid relate to autoantibody profile against the NH2- and COOH-terminal regions of the BP180 ectodomain. J. Invest. Dermatol. 2002, 119, 1065-1073. 
121. Karlsson, F.A.; Burman, P.; Lööf, L.; Mårdh, S. Major parietal cell antigen in autoimmune gastritis with pernicious anemia is the acid-producing $\mathrm{H}^{+}, \mathrm{K}^{+}$-adenosine triphosphatase of the stomach. J. Clin. Invest. 1988, 81, 475-479.

122. Toh, B.H.; Gleeson, P.A.; Simpson, R.J.; Moritz, R.L.; Callaghan, J.M.; Goldkorn, I.; Jones, C.M.; Martinelli, T.M.; Mu, F.T.; Humphris, D.C. The 60- to $90-\mathrm{kDa}$ parietal cell autoantigen associated with autoimmune gastritis is a beta subunit of the gastric $\mathrm{H}+/ \mathrm{K}(+)$-ATPase (proton pump). Proc. Natl. Acad. Sci. USA 1990, 87, 6418-6422.

123. Guéant, J.L.; Safi, A.; Aimone-Gastin, I.; Rabesona, H.; Bronowicki, J.P.; Plénat, F.; Bigard, M.A.; Haertlé, T. Autoantibodies in pernicious anemia type I patients recognize sequence $251-256$ in human intrinsic factor. Proc. Assoc. Am. Phys. 1997, 109, 462-469.

124. Andersen, C.B.F.; Madsen, M.; Storm, T.; Moestrup, S.K.; Andersen, G.R. Structural basis for receptor recognition of vitamin-B(12)-intrinsic factor complexes. Nature 2010, 464, 445-448.

125. Schade, S.G.; Feick, P.; Muckerheide, M.; Schilling, R.F. Occurrence in gastric juice of antibody to a complex of intrinsic factor and vitamin B12. N. Engl. J. Med. 1966, 275, 528-531.

126. Rose, M.S.; Chanarin, I. Dissociation of intrinsic factor from its antibody: Application to study of pernicious anaemia gastric juice specimens. Br. Med. J. 1969, 1, 468-470.

127. Burman, P.; Kämpe, O.; Kraaz, W.; Lööf, L.; Smolka, A.; Karlsson, A.; Karlsson-Parra, A. A study of autoimmune gastritis in the postpartum period and at a 5-year follow-up. Gastroenterology 1992, 103, 934-942.

128. Alonso, N.; Granada, M.L.; Soldevila, B.; Salinas, I.; Joaquin, C.; Reverter, J.L.; Juncà, J.; Martínez Cáceres, E.M.; Sanmartí, A. Serum autoimmune gastritis markers, pepsinogen I and parietal cell antibodies, in patients with type 1 diabetes mellitus: A 5-year prospective study. J. Endocrinol. Invest. 2011, 34, 340-344.

129. Toh, B.-H.; Chan, J.; Kyaw, T.; Alderuccio, F. Cutting edge issues in autoimmune gastritis. Clin. Rev. Allergy Immunol. 2012, 42, 269-278.

130. Di Sabatino, A.; Lenti, M.V.; Giuffrida, P.; Vanoli, A.; Corazza, G.R. New insights into mechanisms underlying autoimmune diseases of the gastrointestinal tract. Autoimmun. Rev. 2015, 14, doi:10.1016/j.autrev.2015.08.004.

131. Van Venrooij, W.J.; Zendman, A.J.W.; Pruijn, G.J.M. Autoantibodies to citrullinated antigens in (early) rheumatoid arthritis. Autoimmun. Rev. 2006, 6, 37-41.

132. Cook, A.D.; Rowley, M.J.; Stockman, A.; Muirden, K.D.; Mackay, I.R. Specificity of antibodies to type II collagen in early rheumatoid arthritis. J. Rheumatol. 1994, 21, 1186-1191.

133. Cook, A.D.; Gray, R.; Ramshaw, J.; Mackay, I.R.; Rowley, M.J. Antibodies against the CB10 fragment of type II collagen in rheumatoid arthritis. Arthritis Res. Ther. 2004, 6, R477-R483.

134. Fujii, K.; Tsuji, M.; Kitamura, A.; Murota, K. The diagnostic significance of anti-type II collagen antibody assay in rheumatoid arthritis. Int. Orthop. 1992, 16, 272-276.

135. Pereira, R.S.; Black, C.M.; Duance, V.C.; Jones, V.E.; Jacoby, R.K.; Welsh, K.I. Disappearing collagen antibodies in rheumatoid arthritis. Lancet 1985, 2, 501-502.

136. Stuart, J.M.; Dixon, F.J. Serum transfer of collagen-induced arthritis in mice. J. Exp. Med. 1983, 158, 378-392. 
137. Holmdahl, R.; Rubin, K.; Klareskog, L.; Larsson, E.; Wigzell, H. Characterization of the antibody response in mice with type II collagen-induced arthritis, using monoclonal anti-type II collagen antibodies. Arthritis Rheum. 1986, 29, 400-410.

138. Kagari, T.; Tanaka, D.; Doi, H.; Shimozato, T. Essential role of Fc gamma receptors in anti-type II collagen antibody-induced arthritis. J. Immunol. 2003, 170, 4318-4324.

139. Kagari, T.; Doi, H.; Shimozato, T. The importance of IL-1 beta and TNF-alpha, and the noninvolvement of IL-6, in the development of monoclonal antibody-induced arthritis. J. Immunol. 2002, 169, 1459-1466.

140. Tanaka, D.; Kagari, T.; Doi, H.; Shimozato, T. Essential role of neutrophils in anti-type II collagen antibody and lipopolysaccharide-induced arthritis. Immunology 2006, 119, 195-202.

141. Wang, Y.; Kristan, J.; Hao, L.; Lenkoski, C.S.; Shen, Y.; Matis, L.A. A role for complement in antibody-mediated inflammation: C5-deficient DBA/1 mice are resistant to collagen-induced arthritis. J. Immunol. 2000, 164, 4340-4347.

142. Watson, W.C.; Brown, P.S.; Pitcock, J.A.; Townes, A.S. Passive transfer studies with type II collagen antibody in B10.D2/old and new line and C57B1/6 normal and beige (Chediak-Higashi) strains: Evidence of important roles for C5 and multiple inflammatory cell types in the development of erosive arthritis. Arthritis Rheum. 1987, 30, 460-465.

143. Grant, E.P.; Picarella, D.; Burwell, T.; Delaney, T.; Croci, A.; Avitahl, N.; Humbles, A.A.; Gutierrez-Ramos, J.-C.; Briskin, M.; Gerard, C.; et al. Essential role for the C5a receptor in regulating the effector phase of synovial infiltration and joint destruction in experimental arthritis. J. Exp. Med. 2002, 196, 1461-1471.

144. Manivel, V.A.; Sohrabian, A.; Wick, M.C.; Mullazehi, M.; Håkansson, L.D.; Rönnelid, J. Anti-type II collagen immune complex-induced granulocyte reactivity is associated with joint erosions in RA patients with anti-collagen antibodies. Arthritis Res. Ther. 2015, 17, 8.

145. Mullazehi, M.; Mathsson, L.; Lampa, J.; Rönnelid, J. Surface-bound anti-type II collagen-containing immune complexes induce production of tumor necrosis factor alpha, interleukin-1beta, and interleukin-8 from peripheral blood monocytes via Fc gamma receptor IIA: A potential pathophysiologic mechanism for humoral anti-type II collagen immunity in arthritis. Arthritis Rheum. 2006, 54, 1759-1771.

146. Mullazehi, M.; Mathsson, L.; Lampa, J.; Rönnelid, J. High anti-collagen type-II antibody levels and induction of proinflammatory cytokines by anti-collagen antibody-containing immune complexes in vitro characterise a distinct rheumatoid arthritis phenotype associated with acute inflammation at the time of disease onset. Ann. Rheum. Dis. 2007, 66, 537-541.

147. Schulte, S.; Unger, C.; Mo, J.A.; Wendler, O.; Bauer, E.; Frischholz, S.; von der Mark, K.; Kalden, J.R.; Holmdahl, R.; Burkhardt, H. Arthritis-related B cell epitopes in collagen II are conformation-dependent and sterically privileged in accessible sites of cartilage collagen fibrils. J. Biol. Chem. 1998, 273, 1551-1561.

148. Kraetsch, H.G.; Unger, C.; Wernhoff, P.; Schneider, C.; Kalden, J.R.; Holmdahl, R.; Burkhardt, H. Cartilage-specific autoimmunity in rheumatoid arthritis: Characterization of a triple helical B cell epitope in the integrin-binding-domain of collagen type II. Eur. J. Immunol. 2001, 31, 1666-1673.

149. Gray, R.E.; Seng, N.; Mackay, I.R.; Rowley, M.J. Measurement of antibodies to collagen II by inhibition of collagen fibril formation in vitro. J. Immunol. Methods 2004, 285, 55-61. 
150. Rowley, M.J.; Nandakumar, K.S.; Holmdahl, R. The role of collagen antibodies in mediating arthritis. Mod. Rheumatol. 2008, 18, 429-441.

151. Hutamekalin, P.; Saito, T.; Yamaki, K.; Mizutani, N.; Brand, D.D.; Waritani, T.; Terato, K.; Yoshino, S. Collagen antibody-induced arthritis in mice: Development of a new arthritogenic 5-clone cocktail of monoclonal anti-type II collagen antibodies. J. Immunol. Methods 2009, 343, 49-55.

152. Nandakumar, K.S.; Holmdahl, R. Efficient promotion of collagen antibody induced arthritis (CAIA) using four monoclonal antibodies specific for the major epitopes recognized in both collagen induced arthritis and rheumatoid arthritis. J. Immunol. Methods 2005, 304, 126-136.

153. Bajtner, E.; Nandakumar, K.S.; Engström, A.; Holmdahl, R. Chronic development of collagen-induced arthritis is associated with arthritogenic antibodies against specific epitopes on type II collagen. Arthritis Res. Ther. 2005, 7, R1148-R1157.

154. Burkhardt, H.; Koller, T.; Engström, A.; Nandakumar, K.S.; Turnay, J.; Kraetsch, H.G.; Kalden, J.R.; Holmdahl, R. Epitope-specific recognition of type II collagen by rheumatoid arthritis antibodies is shared with recognition by antibodies that are arthritogenic in collagen-induced arthritis in the mouse. Arthritis Rheum. 2002, 46, 2339-2348.

155. Chang, X.; Yamada, R.; Suzuki, A.; Sawada, T.; Yoshino, S.; Tokuhiro, S.; Yamamoto, K. Localization of peptidylarginine deiminase 4 (PADI4) and citrullinated protein in synovial tissue of rheumatoid arthritis. Rheumatology (Oxf.) 2005, 44, 40-50.

156. Foulquier, C.; Sebbag, M.; Clavel, C.; Chapuy-Regaud, S.; Badine, R.A.; Méchin, M.-C.; Vincent, C.; Nachat, R.; Yamada, M.; Takahara, H.; et al. Peptidyl arginine deiminase type 2 (PAD-2) and PAD-4 but not PAD-1, PAD-3, and PAD-6 are expressed in rheumatoid arthritis synovium in close association with tissue inflammation. Arthritis Rheum. 2007, 56, 3541-3553.

157. Gregersen, P.K.; Silver, J.; Winchester, R.J. The shared epitope hypothesis. An approach to understanding the molecular genetics of susceptibility to rheumatoid arthritis. Arthritis Rheum. 1987, 30, 1205-1213.

158. Heesters, B.A.; Chatterjee, P.; Kim, Y.-A.; Gonzalez, S.F.; Kuligowski, M.P.; Kirchhausen, T.; Carroll, M.C. Endocytosis and recycling of immune complexes by follicular dendritic cells enhances B cell antigen binding and activation. Immunity 2013, 38, 1164-1175.

159. Sokolove, J.; Johnson, D.S.; Lahey, L.J.; Wagner, C.A.; Cheng, D.; Thiele, G.M.; Michaud, K.; Sayles, H.; Reimold, A.M.; Caplan, L.; et al. Rheumatoid factor as a potentiator of anti-citrullinated protein antibody-mediated inflammation in rheumatoid arthritis. Arthritis Rheum. 2014, 66, 813-821.

160. Manoussakis, M.; Talal, N.; Moutsopoulos, H.M. Sjogren's Syndrome. In The Autoimmune Diseases, 2nd ed.; Rose, N.R., Mackay, I.R., Eds.; Academic Press: San Diego, CA, USA, 1998; pp. 381-404.

161. Gordon, T.P.; Greer, M.; Reynolds, P.; Guidolin, A.; McNeilage, L.J. Estimation of amounts of anti-La(SS-B) antibody directed against immunodominant epitopes of the $\mathrm{La}(\mathrm{SS}-\mathrm{B})$ autoantigen. Clin. Exp. Immunol. 1991, 85, 402-406.

162. Bacman, S.; Sterin-Borda, L.; Camusso, J.J.; Arana, R.; Hubscher, O.; Borda, E. Circulating antibodies against rat parotid gland M3 muscarinic receptors in primary Sjögren's syndrome. Clin. Exp. Immunol. 1996, 104, 454-459. 
163. Waterman, S.A.; Gordon, T.P.; Rischmueller, M. Inhibitory effects of muscarinic receptor autoantibodies on parasympathetic neurotransmission in Sjögren's syndrome. Arthritis Rheum. 2000, 43, 1647-1654.

164. Jackson, M.W.; Gordon, T.P.; Waterman, S.A. Disruption of intestinal motility by a calcium channel-stimulating autoantibody in type 1 diabetes. Gastroenterology 2004, 126, 819-828.

165. Dawson, L.J.; Stanbury, J.; Venn, N.; Hasdimir, B.; Rogers, S.N.; Smith, P.M. Antimuscarinic antibodies in primary Sjögren's syndrome reversibly inhibit the mechanism of fluid secretion by human submandibular salivary acinar cells. Arthritis Rheum. 2006, 54, 1165-1173.

166. Tsuboi, H.; Matsumoto, I.; Wakamatsu, E.; Nakamura, Y.; Iizuka, M.; Hayashi, T.; Goto, D.; Ito, S.; Sumida, T. New epitopes and function of anti-M3 muscarinic acetylcholine receptor antibodies in patients with Sjögren's syndrome. Clin. Exp. Immunol. 2010, 162, 53-61.

167. Koo, N.-Y.; Li, J.; Hwang, S.-M.; Choi, S.-Y.; Lee, S.J.; Oh, S.-B.; Kim, J.-S.; Lee, E.B.; Song, Y.W.; Park, K. Functional epitope of muscarinic type 3 receptor which interacts with autoantibodies from Sjogren's syndrome patients. Rheumatology (Oxf.) 2008, 47, 828-833.

168. Kim, N.; Shin, Y.; Choi, S.; Namkoong, E.; Kim, M.; Lee, J.; Song, Y.; Park, K. Effect of antimuscarinic autoantibodies in primary Sjögren's syndrome. J. Dent. Res. 2015, 94, 722-728.

169. Park, K.; Park, S.; Jackson, M.W. The inhibitory effects of antimuscarinic autoantibodies in the sera of primary Sjogren syndrome patients on the gastrointestinal motility. Mol. Immunol. 2013, $56,583-587$.

170. Iorio, R.; Lennon, V.A. Neural antigen-specific autoimmune disorders. Immunol. Rev. 2012, 248, 104-121.

171. Fregeau, D.R.; Davis, P.A.; Danner, D.J.; Ansari, A.; Coppel, R.L.; Dickson, E.R.; Gershwin, M.E. Antimitochondrial antibodies of primary biliary cirrhosis recognize dihydrolipoamide acyltransferase and inhibit enzyme function of the branched chain alpha-ketoacid dehydrogenase complex. J. Immunol. 1989, 142, 3815-3820.

172. Stacey, D.W.; Skelly, S.; Watson, T.; Elkon, K.; Weissbach, H.; Brot, N. The inhibition of protein synthesis by IgG containing anti-ribosome $\mathrm{P}$ autoantibodies from systemic lupus erythematosus patients. Arch. Biochem. Biophys. 1988, 267, 398-403.

173. Uibo, R.; Mackay, I.R.; Rowley, M.; Humphries, P.; Armstrong, J.M.; McNeilage, J. Inhibition of enzyme function by human autoantibodies to an autoantigen pyruvate dehydrogenase E2: Different epitope for spontaneous human and induced rabbit autoantibodies. Clin. Exp. Immunol. 1990, 80, 19-24.

174. Wong, R.L.; Katz, M.E.; Ogata, K.; Tan, E.M.; Cohen, S. Inhibition of nuclear DNA synthesis by an autoantibody to proliferating cell nuclear antigen/cyclin. Cell. Immunol. 1987, 110, 443-448.

175. Zanger, U.M.; Hauri, H.P.; Loeper, J.; Homberg, J.C.; Meyer, U.A. Antibodies against human cytochrome P-450db1 in autoimmune hepatitis type II. Proc. Natl. Acad. Sci. USA 1988, 85, 8256-8260.

176. Ma, J.; Chapman, G.V.; Chen, S.L.; Melick, G.; Penny, R.; Breit, S.N. Antibody penetration of viable human cells. I. Increased penetration of human lymphocytes by anti-RNP IgG. Clin. Exp. Immunol. 1991, 84, 83-91. 
177. Lisi, S.; Sisto, M.; Soleti, R.; Saponaro, C.; Scagliusi, P.; D’Amore, M.; Saccia, M.; Maffione, A.B.; Mitolo, V. Fcgamma receptors mediate internalization of anti-Ro and anti-La autoantibodies from Sjögren's syndrome and apoptosis in human salivary gland cell line A-253. J. Oral Pathol. Med. 2007, 36, 511-523.

178. Lisi, S.; D’Amore, M.; Lofrumento, D.; Mitolo, V.; Frassanito, M.A.; Dammacco, F.; Scagliusi, P.; Sisto, M. Modulation of the Fcgamma receptors induced by anti-Ro and anti-La autoantibodies: Observations in salivary gland cells. Rheumatol. Int. 2008, 28, 943-948.

179. Alarcón-Segovia, D.; Llorente, L. Antibody penetration into living cells. IV. Different effects of anti-native DNA and anti-ribonucleoprotein IgG on the cell cycle of activated T gamma cells. Clin. Exp. Immunol. 1983, 52, 365-371.

180. Portales-Pérez, D.; Alarcón-Segovia, D.; Llorente, L.; Ruíz-Argüelles, A.; Abud-Mendoza, C.; Baranda, L.; de la Fuente, H.; Ternynck, T.; González-Amaro, R. Penetrating anti-DNA monoclonal antibodies induce activation of human peripheral blood mononuclear cells. J. Autoimmun. 1998, 11, 563-571.

181. Rivadeneyra-Espinoza, L.; Ruiz-Argüelles, A. Cell-penetrating anti-native DNA antibodies trigger apoptosis through both the neglect and programmed pathways. J. Autoimmun. 2006, 26, 52-56.

182. Ruíz-Argüelles, A.; Pérez-romano, B.; Llorente, L.; Alarcón-Segovia, D.; Castellanos, J.M. Penetration of anti-DNA antibodies into immature live cells. J. Autoimmun. 1998, 11, 547-556.

183. Song, Y.-C.; Sun, G.-H.; Lee, T.-P.; Huang, J.C.; Yu, C.-L.; Chen, C.-H.; Tang, S.-J.; Sun, K.-H. Arginines in the CDR of anti-dsDNA autoantibodies facilitate cell internalization via electrostatic interactions. Eur. J. Immunol. 2008, 38, 3178-3190.

184. Koscec, M.; Koren, E.; Wolfson-Reichlin, M.; Fugate, R.D.; Trieu, E.; Targoff, I.N.; Reichlin, M. Autoantibodies to ribosomal $\mathrm{P}$ proteins penetrate into live hepatocytes and cause cellular dysfunction in culture. J. Immunol. 1997, 159, 2033-2041.

185. Malmborg, A.C.; Shultz, D.B.; Luton, F.; Mostov, K.E.; Richly, E.; Leung, P.S.; Benson, G.D.; Ansari, A.A.; Coppel, R.L.; Gershwin, M.E.; et al. Penetration and co-localization in MDCK cell mitochondria of IgA derived from patients with primary biliary cirrhosis. J. Autoimmun. 1998, 11, $573-580$.

186. Adamus, G. Autoantibody-induced apoptosis as a possible mechanism of autoimmune retinopathy. Autoimmun. Rev. 2003, 2, 63-68.

187. Tezel, G.; Wax, M.B. The mechanisms of hsp27 antibody-mediated apoptosis in retinal neuronal cells. J. Neurosci. 2000, 20, 3552-3562.

188. Reichlin, M. Cellular dysfunction induced by penetration of autoantibodies into living cells: Cellular damage and dysfunction mediated by antibodies to dsDNA and ribosomal P proteins. J. Autoimmun. 1998, 11, 557-561.

189. Adamus, G.; Machnicki, M.; Elerding, H.; Sugden, B.; Blocker, Y.S.; Fox, D.A. Antibodies to recoverin induce apoptosis of photoreceptor and bipolar cells in vivo. J. Autoimmun. 1998, 11, $523-533$.

190. Fuller, J.P.; Stavenhagen, J.B.; Teeling, J.L. New roles for Fc receptors in neurodegeneration-the impact on Immunotherapy for Alzheimer's Disease. Front. Neurosci. 2014, 8, 235.

191. Borges, L.F.; Elliott, P.J.; Gill, R.; Iversen, S.D.; Iversen, L.L. Selective extraction of small and large molecules from the cerebrospinal fluid by Purkinje neurons. Science 1985, 228, 346-348. 
192. Greenlee, J.E.; Burns, J.B.; Rose, J.W.; Jaeckle, K.A.; Clawson, S. Uptake of systemically administered human anticerebellar antibody by rat Purkinje cells following blood-brain barrier disruption. Acta Neuropathol. 1995, 89, 341-345.

193. Greenlee, J.E.; Clawson, S.A.; Hill, K.E.; Wood, B.; Clardy, S.L.; Tsunoda, I.; Carlson, N.G. Anti-Yo antibody uptake and Interaction with its intracellular target antigen causes Purkinje cell death in rat cerebellar slice cultures: A possible mechanism for paraneoplastic cerebellar degeneration in humans with gynecological or breast cancers. PLOS ONE 2015, 10, e0123446.

194. Hill, K.E.; Clawson, S.A.; Rose, J.W.; Carlson, N.G.; Greenlee, J.E. Cerebellar Purkinje cells incorporate immunoglobulins and immunotoxins in vitro: Implications for human neurological disease and immunotherapeutics. J. Neuroinflamm. 2009, 6, doi:10.1186/1742-2094-6-31.

195. Yoshimi, K.; Woo, M.; Son, Y.; Baudry, M.; Thompson, R.F. IgG-immunostaining in the intact rabbit brain: Variable but significant staining of hippocampal and cerebellar neurons with anti-IgG. Brain Res. 2002, 956, 53-66.

196. Ternynck, T.; Avrameas, A.; Ragimbeau, J.; Buttin, G.; Avrameas, S. Immunochemical, structural and translocating properties of anti-DNA antibodies from (NZBXNZW)F1 mice. J. Autoimmun. 1998, 11, 511-521.

197. El-Sayed, A.; Futaki, S.; Harashima, H. Delivery of macromolecules using arginine-rich cell-penetrating peptides: Ways to overcome endosomal entrapment. AAPS J. 2009, 11, 13-22.

198. Melikov, K.; Chernomordik, L.V. Arginine-rich cell penetrating peptides: From endosomal uptake to nuclear delivery. Cell. Mol. Life Sci. 2005, 62, 2739-2749.

199. Rahman, A. Autoantibodies, lupus and the science of sabotage. Rheumatology (Oxf.) 2004, 43, 1326-1336.

200. Greidinger, E.L. Apoptosis in lupus pathogenesis. Front. Biosci. J. Virtual Libr. 2001, 6, D1392-D1402.

201. Navratil, J.S.; Liu, C.-C.; Ahearn, J.M. Apoptosis and autoimmunity. Immunol. Res. 2006, 36, 3-12.

202. Varley, J.; Vincent, A.; Irani, S.R. Clinical and experimental studies of potentially pathogenic brain-directed autoantibodies: Current knowledge and future directions. J. Neurol. 2015, 262, 1081-1095.

203. Baekkeskov, S.; Aanstoot, H.J.; Christgau, S.; Reetz, A.; Solimena, M.; Cascalho, M.; Folli, F.; Richter-Olesen, H.; De Camilli, P.; Camilli, P.D. Identification of the $64 \mathrm{~K}$ autoantigen in insulin-dependent diabetes as the GABA-synthesizing enzyme glutamic acid decarboxylase. Nature 1990, 347, 151-156.

204. Rowley, M.J.; Mackay, I.R.; Chen, Q.Y.; Knowles, W.J.; Zimmet, P.Z. Antibodies to glutamic acid decarboxylase discriminate major types of diabetes mellitus. Diabetes 1992, 41, 548-551.

205. Solimena, M.; Folli, F.; Denis-Donini, S.; Comi, G.C.; Pozza, G.; De Camilli, P.; Vicari, A.M. Autoantibodies to glutamic acid decarboxylase in a patient with stiff-man syndrome, epilepsy, and type I diabetes mellitus. N. Engl. J. Med. 1988, 318, 1012-1020.

206. Solimena, M.; Folli, F.; Aparisi, R.; Pozza, G.; De Camilli, P. Autoantibodies to GABA-ergic neurons and pancreatic beta cells in stiff-man syndrome. N. Engl. J. Med. 1990, 322, 1555-1560. 
207. Pittock, S.J.; Yoshikawa, H.; Ahlskog, J.E.; Tisch, S.H.; Benarroch, E.E.; Kryzer, T.J.; Lennon, V.A. Glutamic acid decarboxylase autoimmunity with brainstem, extrapyramidal, and spinal cord dysfunction. Mayo Clin. Proc. 2006, 81, 1207-1214.

208. Saiz, A.; Blanco, Y.; Sabater, L.; González, F.; Bataller, L.; Casamitjana, R.; Ramió-Torrentà, L.; Graus, F. Spectrum of neurological syndromes associated with glutamic acid decarboxylase antibodies: Diagnostic clues for this association. Brain J. Neurol. 2008, 131, 2553-2563.

209. Dalakas, M.C.; Li, M.; Fujii, M.; Jacobowitz, D.M. Stiff person syndrome: Quantification, specificity, and intrathecal synthesis of GAD65 antibodies. Neurology 2001, 57, 780-784.

210. Raju, R.; Foote, J.; Banga, J.P.; Hall, T.R.; Padoa, C.J.; Dalakas, M.C.; Ortqvist, E.; Hampe, C.S. Analysis of GAD65 autoantibodies in Stiff-Person syndrome patients. J. Immunol. 2005, 175, 7755-7762.

211. Skorstad, G.; Hestvik, A.L.; Torjesen, P.; Alvik, K.; Vartdal, F.; Vandvik, B.; Holmøy, T. GAD65 IgG autoantibodies in stiff person syndrome: Clonality, avidity and persistence. Eur. J. Neurol. 2008, 15, 973-980.

212. Chang, T.; Alexopoulos, H.; McMenamin, M.; Carvajal-González, A.; Alexander, S.K.; Deacon, R.; Erdelyi, F.; Szabó, G.; Gabor, S.; Lang, B.; et al. Neuronal surface and glutamic acid decarboxylase autoantibodies in Nonparaneoplastic stiff person syndrome. JAMA Neurol. 2013, 70, 1140-1149.

213. Rakocevic, G.; Raju, R.; Dalakas, M.C. Anti-glutamic acid decarboxylase antibodies in the serum and cerebrospinal fluid of patients with stiff-person syndrome: Correlation with clinical severity. Arch. Neurol. 2004, 61, 902-904.

214. Seissler, J.; Amann, J.; Mauch, L.; Haubruck, H.; Wolfahrt, S.; Bieg, S.; Richter, W.; Holl, R.; Heinze, E.; Northemann, W. Prevalence of autoantibodies to the $65-$ and $67-\mathrm{kD}$ isoforms of glutamate decarboxylase in insulin-dependent diabetes mellitus. J. Clin. Invest. 1993, 92, 1394-1399.

215. Velloso, L.A.; Kämpe, O.; Hallberg, A.; Christmanson, L.; Betsholtz, C.; Karlsson, F.A. Demonstration of GAD-65 as the main immunogenic isoform of glutamate decarboxylase in type 1 diabetes and determination of autoantibodies using a radioligand produced by eukaryotic expression. J. Clin. Invest. 1993, 91, 2084-2090.

216. Jayakrishnan, B.; Hoke, D.E.; Langendorf, C.G.; Buckle, A.M.; Rowley, M.J. An analysis of the cross-reactivity of autoantibodies to GAD65 and GAD67 in diabetes. PLoS ONE 2011, 6, doi:10.1371/journal.pone.0018411.

217. Dinkel, K.; Meinck, H.M.; Jury, K.M.; Karges, W.; Richter, W. Inhibition of gamma-aminobutyric acid synthesis by glutamic acid decarboxylase autoantibodies in stiff-man syndrome. Ann. Neurol. 1998, 44, 194-201.

218. Murinson, B.B. Stiff-person syndrome. Neurologist 2004, 10, 131-137.

219. Richter, W.; Seissler, J.; Northemann, W.; Wolfahrt, S.; Meinck, H.M.; Scherbaum, W.A. Cytoplasmic islet cell antibodies recognize distinct islet antigens in IDDM but not in stiff man syndrome. Diabetes 1993, 42, 1642-1648.

220. Tuomi, T.; Rowley, M.J.; Knowles, W.J.; Chen, Q.Y.; McAnally, T.; Zimmet, P.Z.; Mackay, I.R. Autoantigenic properties of native and denatured glutamic acid decarboxylase: Evidence for a conformational epitope. Clin. Immunol. Immunopathol. 1994, 71, 53-59. 
221. Ziegler, B.; Schlosser, M.; Lühder, F.; Strebelow, M.; Augstein, P.; Northemann, W.; Powers, A.C.; Ziegler, M. Murine monoclonal glutamic acid decarboxylase (GAD)65 antibodies recognize autoimmune-associated GAD epitope regions targeted in patients with type 1 diabetes mellitus and stiff-man syndrome. Acta Diabetol. 1996, 33, 225-231.

222. Butler, M.H.; Solimena, M.; Dirkx, R.; Hayday, A.; De Camilli, P. Identification of a dominant epitope of glutamic acid decarboxylase (GAD-65) recognized by autoantibodies in stiff-man syndrome. J. Exp. Med. 1993, 178, 2097-2106.

223. Richter, W.; Shi, Y.; Baekkeskov, S. Autoreactive epitopes defined by diabetes-associated human monoclonal antibodies are localized in the middle and C-terminal domains of the smaller form of glutamate decarboxylase. Proc. Natl. Acad. Sci. USA 1993, 90, 2832-2836.

224. Kim, J.; Namchuk, M.; Bugawan, T.; Fu, Q.; Jaffe, M.; Shi, Y.; Aanstoot, H.J.; Turck, C.W.; Erlich, H.; Lennon, V.; et al. Higher autoantibody levels and recognition of a linear NH2-terminal epitope in the autoantigen GAD65, distinguish stiff-man syndrome from insulin-dependent diabetes mellitus. J. Exp. Med. 1994, 180, 595-606.

225. Al-Bukhari, T.A.M.A.; Radford, P.M.; Bouras, G.; Davenport, C.; Trigwell, S.M.; Bottazzo, G.-F.; Lai, M.; Schwartz, H.L.; Tighe, P.J.; Todd, I. Distinct antigenic features of linear epitopes at the $\mathrm{N}$-terminus and C-terminus of $65 \mathrm{kDa}$ glutamic acid decarboxylase (GAD65): Implications for autoantigen modification during pathogenesis. Clin. Exp. Immunol. 2002, 130, 131-139.

226. Padoa, C.J.; Banga, J.P.; Madec, A.-M.; Ziegler, M.; Schlosser, M.; Ortqvist, E.; Kockum, I.; Palmer, J.; Rolandsson, O.; Binder, K.A.; et al. Recombinant Fabs of human monoclonal antibodies specific to the middle epitope of GAD65 inhibit type 1 diabetes-specific GAD65Abs. Diabetes 2003, 52, 2689-2695.

227. Geis, C.; Weishaupt, A.; Grünewald, B.; Wultsch, T.; Reif, A.; Gerlach, M.; Dirkx, R.; Solimena, M.; Perani, D.; Heckmann, M.; et al. Human stiff-person syndrome IgG induces anxious behavior in rats. PLoS ONE 2011, 6, doi:10.1371/journal.pone.0016775.

228. Hampe, C.S.; Petrosini, L.; De Bartolo, P.; Caporali, P.; Cutuli, D.; Laricchiuta, D.; Foti, F.; Radtke, J.R.; Vidova, V.; Honnorat, J.; et al. Monoclonal antibodies to $65 \mathrm{kDa}$ glutamate decarboxylase induce epitope specific effects on motor and cognitive functions in rats. Orphanet J. Rare Dis. 2013, 8, 82.

229. Hansen, N.; Grünewald, B.; Weishaupt, A.; Colaço, M.N.; Toyka, K.V.; Sommer, C.; Geis, C. Human Stiff person syndrome IgG-containing high-titer anti-GAD65 autoantibodies induce motor dysfunction in rats. Exp. Neurol. 2013, 239, 202-209.

230. Manto, M.; Honnorat, J.; Hampe, C.S.; Guerra-Narbona, R.; López-Ramos, J.C.; Delgado-García, J.M.; Saitow, F.; Suzuki, H.; Yanagawa, Y.; Mizusawa, H.; et al. Disease-specific monoclonal antibodies targeting glutamate decarboxylase impair GABAergic neurotransmission and affect motor learning and behavioral functions. Front. Behav. Neurosci. 2015, 9, doi:10.3389/fnbeh.2015.00078.

231. Manto, M.-U.; Laute, M.-A.; Aguera, M.; Rogemond, V.; Pandolfo, M.; Honnorat, J. Effects of anti-glutamic acid decarboxylase antibodies associated with neurological diseases. Ann. Neurol. 2007, 61, 544-551.

232. Whittingham, S.; Mathews, J.D.; Mackay, I.R.; Stocks, A.E.; Ungar, B.; Martin, F.I.R. Diabetes mellitus, autoimmunity, and ageing. Lancet 1971, 297, 763-767. 
233. Marner, B.; Lernmark, A.; Ludvigsson, J.; MacKay, P.; Matsuba, I.; Nerup, J.; Rabinovitch, A. Islet cell antibodies in insulin-dependent (type 1) diabetic children treated with plasmapheresis. Diabetes Res. 1985, 2, 231-236.

234. Dalakas, M.C.; Fujii, M.; Li, M.; Lutfi, B.; Kyhos, J.; McElroy, B. High-dose intravenous immune globulin for stiff-person syndrome. N. Engl. J. Med. 2001, 345, 1870-1876.

235. Dalakas, M.C. Intravenous immunoglobulin in patients with anti-GAD antibody-associated neurological diseases and patients with inflammatory myopathies: Effects on clinicopathological features and immunoregulatory genes. Clin. Rev. Allergy Immunol. 2005, 29, 255-269.

236. Bacorro, E.A.; Tehrani, R. Stiff-person syndrome: Persistent elevation of glutamic acid decarboxylase antibodies despite successful treatment with rituximab. J. Clin. Rheumatol. Pract. Rep. Rheum. Musculoskelet. Dis. 2010, 16, 237-239.

237. Baker, M.R.; Das, M.; Isaacs, J.; Fawcett, P.R.W.; Bates, D. Treatment of stiff person syndrome with rituximab. J. Neurol. Neurosurg. Psychiatry 2005, 76, 999-1001.

238. Katoh, N.; Matsuda, M.; Ishii, W.; Morita, H.; Ikeda, S. Successful treatment with rituximab in a patient with stiff-person syndrome complicated by dysthyroid ophthalmopathy. Int. Med. Tokyo Jpn. 2010, 49, 237-241.

239. Rizzi, M.; Knoth, R.; Hampe, C.S.; Lorenz, P.; Gougeon, M.-L.; Lemercier, B.; Venhoff, N.; Ferrera, F.; Salzer, U.; Thiesen, H.-J.; et al. Long-lived plasma cells and memory B cells produce pathogenic anti-GAD65 autoantibodies in Stiff Person Syndrome. PLoS ONE 2010, 5, doi:10.1371/journal.pone.0010838.

240. Venhoff, N.; Rizzi, M.; Salzer, U.; Bossaller, L.; Thoden, J.; Eibel, H.; Walker, U.A. Monozygotic twins with stiff person syndrome and autoimmune thyroiditis: Rituximab inefficacy in a double-blind, randomised, placebo controlled crossover study. Ann. Rheum. Dis. 2009, 68, 1506-1508.

241. Jin, H.; Wu, H.; Osterhaus, G.; Wei, J.; Davis, K.; Sha, D.; Floor, E.; Hsu, C.-C.; Kopke, R.D.; $\mathrm{Wu}$, J.-Y. Demonstration of functional coupling between gamma-aminobutyric acid (GABA) synthesis and vesicular GABA transport into synaptic vesicles. Proc. Natl. Acad. Sci. USA 2003, 100, 4293-4298.

242. Kaufman, D.L.; Houser, C.R.; Tobin, A.J. Two forms of the gamma-aminobutyric acid synthetic enzyme glutamate decarboxylase have distinct intraneuronal distributions and cofactor interactions. J. Neurochem. 1991, 56, 720-723.

243. Fenalti, G.; Law, R.H.P.; Buckle, A.M.; Langendorf, C.; Tuck, K.; Rosado, C.J.; Faux, N.G.; Mahmood, K.; Hampe, C.S.; Banga, J.P.; et al. GABA production by glutamic acid decarboxylase is regulated by a dynamic catalytic loop. Nat. Struct. Mol. Biol. 2007, 14, 280-286.

244. Patel, A.B.; de Graaf, R.A.; Martin, D.L.; Battaglioli, G.; Behar, K.L. Evidence that GAD65 mediates increased GABA synthesis during intense neuronal activity in vivo. J. Neurochem. 2006, 97, 385-396.

245. Gresa-Arribas, N.; Ariño, H.; Martínez-Hernández, E.; Petit-Pedrol, M.; Sabater, L.; Saiz, A.; Dalmau, J.; Graus, F. Antibodies to inhibitory synaptic proteins in neurological syndromes associated with glutamic acid decarboxylase autoimmunity. PLoS ONE 2015, 10, doi:10.1371/journal.pone.0121364. 
246. Piquer, S.; Belloni, C.; Lampasona, V.; Bazzigaluppi, E.; Vianello, M.; Giometto, B.; Bosi, E.; Bottazzo, G.F.; Bonifacio, E. Humoral autoimmune responses to glutamic acid decarboxylase have similar target epitopes and subclass that show titer-dependent disease association. Clin. Immunol. 2005, 117, 31-35.

247. Madec, A.M.; Rousset, F.; Ho, S.; Robert, F.; Thivolet, C.; Orgiazzi, J.; Lebecque, S. Four IgG anti-islet human monoclonal antibodies isolated from a type 1 diabetes patient recognize distinct epitopes of glutamic acid decarboxylase 65 and are somatically mutated. J. Immunol. 1996, 156, 3541-3549.

248. Richter, W.; Endl, J.; Eiermann, T.H.; Brandt, M.; Kientsch-Engel, R.; Thivolet, C.; Jungfer, H.; Scherbaum, W.A. Human monoclonal islet cell antibodies from a patient with insulin-dependent diabetes mellitus reveal glutamate decarboxylase as the target antigen. Proc. Natl. Acad. Sci. USA 1992, 89, 8467-8471.

249. Syren, K.; Lindsay, L.; Stoehrer, B.; Jury, K.; Lühder, F.; Baekkeskov, S.; Richter, W. Immune reactivity of diabetes-associated human monoclonal autoantibodies defines multiple epitopes and detects two domain boundaries in glutamate decarboxylase. J. Immunol. 1996, 157, 5208-5214.

250. Tremble, J.; Morgenthaler, N.G.; Vlug, A.; Powers, A.C.; Christie, M.R.; Scherbaum, W.A.; Banga, J.P. Human B cells secreting immunoglobulin G to glutamic acid decarboxylase-65 from a nondiabetic patient with multiple autoantibodies and Graves' disease: A comparison with those present in type 1 diabetes. J. Clin. Endocrinol. Metab. 1997, 82, 2664-2670.

251. Fenalti, G.; Hampe, C.S.; Arafat, Y.; Law, R.H.P.; Banga, J.P.; Mackay, I.R.; Whisstock, J.C.; Buckle, A.M.; Rowley, M.J. COOH-terminal clustering of autoantibody and T-cell determinants on the structure of GAD65 provide insights into the molecular basis of autoreactivity. Diabetes 2008, 57, 1293-1301.

252. Tuomilehto, J.; Zimmet, P.; Mackay, I.R.; Koskela, P.; Vidgren, G.; Toivanen, L.; Tuomilehto-Wolf, E.; Kohtamäki, K.; Stengård, J.; Rowley, M.J. Antibodies to glutamic acid decarboxylase as predictors of insulin-dependent diabetes mellitus before clinical onset of disease. Lancet 1994, 343, 1383-1385.

253. Ishida, K.; Mitoma, H.; Song, S.Y.; Uchihara, T.; Inaba, A.; Eguchi, S.; Kobayashi, T.; Mizusawa, H. Selective suppression of cerebellar GABAergic transmission by an autoantibody to glutamic acid decarboxylase. Ann. Neurol. 1999, 46, 263-267.

254. Ishida, K.; Mitoma, H.; Mizusawa, H. Reversibility of cerebellar GABAergic synapse impairment induced by anti-glutamic acid decarboxylase autoantibodies. J. Neurol. Sci. 2008, 271, 186-190.

255. Mitoma, H.; Song, S.Y.; Ishida, K.; Yamakuni, T.; Kobayashi, T.; Mizusawa, H. Presynaptic impairment of cerebellar inhibitory synapses by an autoantibody to glutamate decarboxylase. J. Neurol. Sci. 2000, 175, 40-44.

256. Mitoma, H.; Ishida, K.; Shizuka-Ikeda, M.; Mizusawa, H. Dual impairment of GABAA- and GABAB-receptor-mediated synaptic responses by autoantibodies to glutamic acid decarboxylase. J. Neurol. Sci. 2003, 208, 51-56.

257. Takenoshita, H.; Shizuka-Ikeda, M.; Mitoma, H.; Song, S.; Harigaya, Y.; Igeta, Y.; Yaguchi, M.; Ishida, K.; Shoji, M.; Tanaka, M.; et al. Presynaptic inhibition of cerebellar GABAergic transmission by glutamate decarboxylase autoantibodies in progressive cerebellar ataxia. J. Neurol. Neurosurg. Psychiatry 2001, 70, 386-389. 
258. Gershwin, M.E.; Mackay, I.R.; Sturgess, A.; Coppel, R.L. Identification and specificity of a cDNA encoding the $70 \mathrm{kd}$ mitochondrial antigen recognized in primary biliary cirrhosis. J. Immunol. 1987, 138, 3525-3531.

259. Csepregi, A.; Szodoray, P.; Zeher, M. Do autoantibodies predict autoimmune liver disease in primary Sjögren's syndrome? Data of 180 patients upon a 5 year follow-up. Scand. J. Immunol. 2002, 56, 623-629.

260. Kisand, K.E.; Metsküla, K.; Kisand, K.V.; Kivik, T.; Gershwin, M.E.; Uibo, R. The follow-up of asymptomatic persons with antibodies to pyruvate dehydrogenase in adult population samples. J. Gastroenterol. 2001, 36, 248-254.

261. Metcalf, J.V.; Mitchison, H.C.; Palmer, J.M.; Jones, D.E.; Bassendine, M.F.; James, O.F. Natural history of early primary biliary cirrhosis. Lancet 1996, 348, 1399-1402.

262. Mitchison, H.C.; Bassendine, M.F.; Hendrick, A.; Bennett, M.K.; Bird, G.; Watson, A.J.; James, O.F. Positive antimitochondrial antibody but normal alkaline phosphatase: Is this primary biliary cirrhosis? Hepatology 1986, 6, 1279-1284.

263. Lleo, A.; Invernizzi, P.; Mackay, I.-R.; Prince, H.; Zhong, R.-Q.; Gershwin, M.-E. Etiopathogenesis of primary biliary cirrhosis. World J. Gastroenterol. 2008, 14, 3328-3337.

264. Chen, R.C.Y.; Naiyanetr, P.; Shu, S.-A.; Wang, J.; Yang, G.-X.; Kenny, T.P.; Guggenheim, K.C.; Butler, J.D.; Bowlus, C.; Tao, M.-H.; et al. Antimitochondrial antibody heterogeneity and the xenobiotic etiology of primary biliary cirrhosis. Hepatology 2013, 57, 1498-1508.

265. Rowley, M.J.; Maeda, T.; Mackay, I.R.; Loveland, B.E.; McMullen, G.L.; Tribbick, G.; Bernard, C.C. Differing epitope selection of experimentally-induced and natural antibodies to a disease-specific autoantigen, the E2 subunit of pyruvate dehydrogenase complex (PDC-E2). Int. Immunol. 1992, 4, 1245-1253.

266. Van de Water, J.; Fregeau, D.; Davis, P.; Ansari, A.; Danner, D.; Leung, P.; Coppel, R.; Gershwin, M.E. Autoantibodies of primary biliary cirrhosis recognize dihydrolipoamide acetyltransferase and inhibit enzyme function. J. Immunol. 1988, 141, 2321-2324.

267. Van de Water, J.; Gerson, L.B.; Ferrell, L.D.; Lake, J.R.; Coppel, R.L.; Batts, K.P.; Wiesner, R.H.; Gershwin, M.E. Immunohistochemical evidence of disease recurrence after liver transplantation for primary biliary cirrhosis. Hepatology 1996, 24, 1079-1084.

268. Yip, T.T.; van de Water, J.; Gershwin, M.E.; Coppel, R.L.; Hutchens, T.W. Cryptic antigenic determinants on the extracellular pyruvate dehydrogenase complex/mimeotope found in primary biliary cirrhosis. A probe by affinity mass spectrometry. J. Biol. Chem. 1996, 271, 32825-32833.

269. Nishio, A.; van de Water, J.; Leung, P.S.; Joplin, R.; Neuberger, J.M.; Lake, J.; Björkland, A.; Tötterman, T.H.; Peters, M.; Worman, H.J.; et al. Comparative studies of antimitochondrial autoantibodies in sera and bile in primary biliary cirrhosis. Hepatology 1997, 25, 1085-1089.

270. Palmer, J.M.; Doshi, M.; Kirby, J.A.; Yeaman, S.J.; Bassendine, M.F.; Jones, D.E. Secretory autoantibodies in primary biliary cirrhosis (PBC). Clin. Exp. Immunol. 2000, 122, 423-428.

271. Reynoso-Paz, S.; Leung, P.S.; van de Water, J.; Tanaka, A.; Munoz, S.; Bass, N.; Lindor, K.; Donald, P.J.; Coppel, R.L.; Ansari, A.A.; et al. Evidence for a locally driven mucosal response and the presence of mitochondrial antigens in saliva in primary biliary cirrhosis. Hepatology 2000, 31, 24-29. 
272. Tanaka, A.; Nalbandian, G.; Leung, P.S.; Benson, G.D.; Munoz, S.; Findor, J.A.; Branch, A.D.; Coppel, R.L.; Ansari, A.A.; Gershwin, M.E. Mucosal immunity and primary biliary cirrhosis: Presence of antimitochondrial antibodies in urine. Hepatology 2000, 32, 910-915.

273. Tanaka, A.; Nezu, S.; Uegaki, S.; Mikami, M.; Okuyama, S.; Kawamura, N.; Aiso, M.; Gershwin, M.E.; Takahashi, S.-I.; Selmi, C.; et al. The clinical significance of IgA antimitochondrial antibodies in sera and saliva in primary biliary cirrhosis. Ann. NY Acad. Sci. 2007, 1107, 259-270.

274. Matsumura, S.; van de Water, J.; Leung, P.; Odin, J.A.; Yamamoto, K.; Gores, G.J.; Mostov, K.; Ansari, A.A.; Coppel, R.L.; Shiratori, Y.; et al. Caspase induction by IgA antimitochondrial antibody: IgA-mediated biliary injury in primary biliary cirrhosis. Hepatology 2004, 39, 1415-1422.

275. Selmi, C.; Meroni, P.L.; Gershwin, M.E. Primary biliary cirrhosis and Sjögren's syndrome: Autoimmune epithelitis. J. Autoimmun. 2012, 39, 34-42.

276. Tsuneyama, K.; van de Water, J.; Nakanuma, Y.; Cha, S.; Ansari, A.; Coppel, R.; Gershwin, M.E. Human combinatorial autoantibodies and mouse monoclonal antibodies to PDC-E2 produce abnormal apical staining of salivary glands in patients with coexistent primary biliary cirrhosis and Sjögren's syndrome. Hepatology 1994, 20, 893-898.

277. Lleo, A.; Selmi, C.; Invernizzi, P.; Podda, M.; Coppel, R.L.; Mackay, I.R.; Gores, G.J.; Ansari, A.A.; van de Water, J.; Gershwin, M.E. Apotopes and the biliary specificity of primary biliary cirrhosis. Hepatology 2009, 49, 871-879.

278. Rong, G.; Zhong, R.; Lleo, A.; Leung, P.S.C.; Bowlus, C.L.; Yang, G.-X.; Yang, C.-Y.; Coppel, R.L.; Ansari, A.A.; Cuebas, D.A.; et al. Epithelial cell specificity and apotope recognition by serum autoantibodies in primary biliary cirrhosis. Hepatology 2011, 54, 196-203.

279. Gregersen, P.K.; Behrens, T.W. Genetics of autoimmune diseases--disorders of immune homeostasis. Nat. Rev. Genet. 2006, 7, 917-928.

280. Cho, J.H.; Gregersen, P.K. Genomics and the multifactorial nature of human autoimmune disease. N. Engl. J. Med. 2011, 365, 1612-1623.

281. Damoiseaux, J.; Andrade, L.E.; Fritzler, M.J.; Shoenfeld, Y. Autoantibodies 2015: From diagnostic biomarkers towards prediction, prognosis and prevention. Autoimmun. Rev. 2015, 14, 555-563.

(C) 2015 by the authors; licensee MDPI, Basel, Switzerland. This article is an open access article distributed under the terms and conditions of the Creative Commons Attribution license (http://creativecommons.org/licenses/by/4.0/). 